\title{
Genetic Resistance of Lactuca spp. against Fusarium oxysporum f. sp. lactucae Race 1
}

Jesse J. Murray, Gulnoz Hisamutdinova, and Germán V. Sandoya

Horticultural Sciences Department, Everglades Research and Education Center, University of Florida/Institute of Food and Agricultural Sciences, Belle Glade, FL

Richard N. Raid

Plant Pathology Department, Everglades Research and Education Center, University of Florida/Institute of Food and Agricultural Sciences, Belle Glade, FL

\section{Stephanie Slinski \\ Yuma Center of Excellence for Desert Agriculture, University of Arizona, Yuma, AZ}

Additional index words. breeding, disease resistance, fusarium wilt, germplasm screening segregation analysis, wildtypes

\begin{abstract}
Fusarium wilt of lettuce is caused by the pathogen Fusarium oxysporum f. sp. lactucae $(\mathrm{Fol})$ and is a growing threat to global lettuce production. Fol was first detected in Florida in $\mathbf{2 0 1 7}$ and was subsequently confirmed as race 1. Management strategies for this long-persisting soil pathogen are limited, time-consuming and expensive, and they may lack efficacy. Identifying diverse sources of genetic resistance is imperative for breeding adapted cultivars with durable resistance. The objectives of this study were to identify sources of resistance against a race 1 isolate of $F o l$ in Florida, delineate the relationship between foliar and taproot symptoms, and investigate the inheritance of resistance and partial resistance in two $F_{2}$ populations. Thirteen experiments were conducted in greenhouse and field locations to characterize the diversity of genetic resistance in the genus Lactuca. Leaf cultivars Dark Lollo Rossa and Galactic; romaine breeding lines 43007, 60182, and C1145; and iceberg breeding line $\mathbf{4 7 0 8 3}$ consistently exhibited low foliar and taproot disease symptoms. Resistance was not identified among the wildtype Lactuca or primitive plant introductions (PI) in this study based on taproot symptoms. An additional test was conducted to study the segregation pattern of $\mathrm{Fol}$ resistance between one resistant and one susceptible accession $(R \times S)$ and one partial resistant and one susceptible accession $(P R \times S)$. The $F_{2}$ population from ' $60182 \times$ PI 358001-1' fit the expected segregation ratio for a single recessive locus model, whereas the ratio for 'Dark Lollo Rossa $\times$ PI 358001-1' did not fit either recessive or dominant single locus models. These sources of resistance are potential candidates for developing commercial cultivars with multiple resistance loci against Fol race 1, especially for the Florida lettuce production system.
\end{abstract}

Fusarium wilt of lettuce (Lactuca sativa L.) is caused by the soilborne fungus Fusarium oxysporum f. sp. lactucae ( $\mathrm{Fol}$ ) and was first described as a root rot around 1955 in Japan (Matuo and Motohashi, 1967). The fungus infects susceptible lettuce roots by colonizing and congesting the central taproot, causing vascular discoloration, as well as foliar symptoms of wilting, stunting, and chlorosis due to constricted water transport (Gordon, 2017). Disease symptoms caused by $\mathrm{Fol}$ appear to be host-specific; however, the pathogen has been detected in asymptomatic taproots of broccoli, cauliflower, and spinach (Scott et al., 2014). Severely infested fields can result in significant crop losses that persist for years due to the production of pathogen survival structures called chlamydospores (Gordon and Koike, 2015). Since its discovery in Japan, race 1 of $F o l$ has been detected in San Joaquin Valley in California; Yuma, AZ; several European countries; and in other worldwide locations including Iran, Egypt, Brazil, and Argentina (El-Sayed et al., 2018; Garibaldi et al., 2002, 2017b, 2019; Guerrero et al., 2020; Hubbard and Gerik, 1993; Malbrán et al., 2014; Matheron and Koike, 2003; Millani, 1999; Pasquali et al., 2007; Ventura and Costa, 2008). Three other $\mathrm{Fol}$ races have been reported, with race 2 occurring only in Japan (Aruga et al., 2012; Seki et al., 2021); race 3 in Japan and Taiwan; and the most recently discovered race 4 has been reported in The Netherlands, Belgium, Italy, England, and Ireland (Claerbout et al., 2018; Gilardi et al., 2017a, 2019; Taylor et al., 2019). It is believed that the pathogen has spread over these large distances through contaminated seed (Garibaldi et al., 2004).
Florida is the third largest lettuce producing state in the United States, and Fol symptoms were first detected in its primary lettuce producing region of the Everglades Agricultural Area (EAA) in 2017 (Murray et al., 2020). Although the pathogen has been confined to a localized region within the EAA, it has the potential to spread to nearby fields through contaminated equipment and will likely remain problematic for years to come, as has occurred in other lettuce production areas (Gordon and Koike, 2015). In fact, long-term fusarium wilt infestations have already occurred in other crops planted Florida, including watermelon (Citrullus lanatus), basil (Ocimum basilicum), Senegal date palm (Phoenix reclinata), cucumber (Cucumis sativus), tomato (Solanum lycopersicum), banana (Musa spp.), and roselle (Hibiscus sabdariffa var. sabdariffa) (Amaradasa et al., 2018; Datnoff et al., 1997; Elliott, 2015; Owen, 1955; Ploetz and Haynes, 2000; Ploetz et al., 1999, 2007). This makes it imperative to derive long-term solutions for mitigating the threat fusarium wilt may pose to the lettuce industry.

Although fallowing fields can reduce the number of viable chlamydospores by roughly half every 6 months, it can take many years before inoculum densities are low enough in the soil to safely replant lettuce (Gordon and Koike, 2015). Effective soil treatments including solarization may be cost-prohibitive, whereas others like methyl bromide may have toxic effects and have been phased out (Desaeger et al., 2017). As a result, breeding lettuce for $\mathrm{Fol}$ resistance offers one of the most effective solutions to reduce producer costs relative to other management strategies (Gordon et al., 2019).

Sources of resistance to fusarium wilt have been identified in cultivated lettuce, and research has shown that romaine cultivars tend to be more resistant than iceberg cultivars, particularly when exposed to warmer temperatures toward the beginning and end of the lettuce growing season in warmer climates (Matheron et al., 2005; Scott et al., $2010 \mathrm{~b}$ ). Previous resistance tests have found a high degree of $\mathrm{Fol}$ race 1 resistance in the romaine cultivars Costa Rica \#4, Caesar, King Henry, Slugger (PI 632267), King Louie, and Valmaine, as well as leaf cultivars Lolla Rossa (PI 617943) and Red Rossa (Matheron and Porchas, 2010; Scott et al., 2012, 2010b). Iceberg cultivars Shinano Hope, Salinas, Salinas 88 (PI 667817), and Calmar show at least moderate resistance (McCreight et al., 2005; Ryder, 1970; Tsuchiya et al., 2004). These cultivars are not adapted to Florida growing conditions; thus, this work includes extensive screening of Florida-adapted germplasm.

There may potentially be new sources of resistance among Lactuca wildtypes, and screening wildtype accessions for Fol resistance has not yet been reported. Although $L$. sativa is the only cultivated species, there are $\approx 100$ other species in the genus Lactuca, with the greatest genetic diversity present in the Mediterranean and Southwest Asia 
regions (Lebeda et al., 2014). Wildtype accessions are valuable sources of resistance against several lettuce pathogens, including the oomycete Bremia lactucae that causes lettuce downy mildew, the Lettuce mosaic virus, and the fungus Verticillium dahliae that causes verticillium wilt (Lebeda et al., 2014; Sandoya et al., 2021; Sequiera, 1978). Recently, several sources of resistance have been identified among accessions of $L$. georgica, $L$. saligna, $L$. serriola, and $L$. virosa for the pathogens Golvinomyces bolayi causing lettuce powdery mildew, B. lactucae, and Lettuce mosaic virus (Beharav, 2021; Giesbers et al., 2018; Maisonneuve et al., 2018; Pelgrom et al., 2019). Hundreds of wildtype accessions are deposited in the U.S. Department of Agriculture Germplasm Information Network (USDA-GRIN) and remain unexplored for novel sources of $\mathrm{Fol}$ resistance.

Characterizing the inheritance of resistance in identified sources provides essential information for cultivar development. McCreight et al. (2005) performed segregation analyses in the $\mathrm{F}_{1}$ generation of six cross combinations and found evidence that 'Costa Rica \#4', 'Salinas', and 'Salinas 88' each contributed a single recessive allele controlling Fol resistance. In contrast, evidence for a single dominant allele controlling resistance in 'Vanda' was found in a segregating population from a cross of 'Vanda $\times$ Gisele' (Cabral et al., 2019). In support of these findings, quantitative trait loci (QTL) analyses conducted in a recombinant inbred lines (RILs) population and in several $\mathrm{F}_{2}$ mapping populations has

Received for publication 9 Aug. 2021. Accepted for publication 29 Sept. 2021.

Published online 19 November 2021

We acknowledge funding from the Hatch Project FLA-ERC-005599, the Foundation for Food and Agriculture Research, Florida Department of Agriculture and Consumer Services Specialty Crop Block Program 19SCBFL0015, Hatch Project ARZT-1361690-H16-100, Arizona Department of Agriculture Specialty Crop Block Grant Program SCBGP20-20, and a Fulbright Scholarship to Gulnoz Hisamutdinova. Thanks to the U.S. Department of Agriculture-Germplasm Information Network and the University of California, Davis (Dr. Maria José Truco) for providing germplasm for these tests. Thanks to J.V. Farms and Gila Valley Farms for Yuma, AZ, for field trial support. We thank Amanda Carroll and Heriberto Trevino for their help with experiments and seed increasing at the Everglades Research and Education Center, the Florida Leafy Vegetable Growers at the Everglades Agricultural Area, TKM-Bengard, and Florida Vegetable Exchange. We acknowledge Glades Crop Care for providing samples of infested lettuce and help with infested field identification. Finally, we recognize Dr. Marcio Resende and Dr. Geoffrey Meru for the internal review and valuable feedback on this manuscript.

Current address for G.H.: Institute of Environmental and Agricultural Biology (X-Bio), University of Tyumen, Russia.

G.V.S. is the corresponding author. E-mail: gsandoyamiranda@ufl.edu.

This is an open access article distributed under the CC BY-NC-ND license (https://creativecommons. org/licenses/by-nc-nd/4.0/). demonstrated distinct QTLs involved in resistance to lettuce Fusarium wilt race 1. These QTLs are found in several linkage groups (LG1, LG2, LG4, LG7, and LG8) of the lettuce genome in 'Valmaine', 'Green Towers', 'King Louie', 'Salinas', and 'Lolla Rossa' (Michelmore et al., 2017; Scott et al., 2012; Seki et al., 2020). Together this indicates that Fol race 1 resistance may be controlled by one to few loci, although several other minor loci may influence the effectiveness of the resistance response (McCreight et al., 2005; Michelmore et al., 2017; Scott et al., 2012; Seki et al., 2020). These results suggest that discovering new accessions with different genetics for resistance may be useful for combining complementary resistance loci into novel cultivars.

The objectives of this study were to identify sources of resistance against $\mathrm{Fol}$ race 1 isolates in Florida, delineate the relationship between foliar and taproot symptoms, and investigate the inheritance of resistance and partial resistance.

\section{Materials and Methods}

\section{Experiments and germplasm}

Field initial screenings. Three replicated field trials (Field 1, Field 2.1, and Field 2.2) were conducted in 2017, 2018, and 2019, respectively, in a plot with confirmed Fol infestation near Belle Glade, FL (Table 1). Each experiment was planted as a randomized complete block design (RCBD) with three blocks to initially test 32 lettuce accessions including commercial cultivars available to lettuce producers in Florida, $\mathrm{Fol}$ differential cultivars, lettuce breeding lines from the University of Florida Institute of Food and Agricultural Sciences (UF/IFAS) germplasm, and the susceptible control 'Chosen' (Supplemental Table 4). The experiments were handplanted in double seed lines in raised beds of high organic matter "muck" soil that were $10 \mathrm{~m}$ long. Lettuce seedlings were thinned after 3 weeks to a distance of $0.30 \mathrm{~m}$ between plants. Plants were grown until maturity using the recommended farming practices for the EAA lettuce production system.

Initial greenhouse screening of wildtypes. Two unreplicated experiments (GH-4 and GH-5) were conducted in a greenhouse at the Everglades Research and Education Center (EREC) of UF/IFAS near Belle Glade, FL (Table 1). GH-4 included 35 PIs of L. sativa and 13 wildtype of $L$. serriola accessions obtained from the USDA-GRIN that represented a global distribution concentrated in the Lactuca Caucasus center of origin (Supplemental Table 1). Seeds for GH-5 were received from the University of California-Davis and consisted of L. serriola (98), L. saligna (5), and Lactuca spp. (3) from countries within the Caucasus center of origin for Lactuca (Supplemental Table 2). Both experiments were planted in an augmented block design (ABD) with five seedlings of the 48 (GH-4 distributed in five blocks) and 106 (GH-5 distributed in 15 blocks) accessions planted once but the controls 'Dark Lollo
Rossa’ (PI 667690), 'Lolla Rossa' (PI 617943), 60182, and 'Chosen' were replicated five times in GH-4 and 15 times in GH-5, respectively (Supplemental Table 4). The cultivar Lolla Rossa was described as resistant (R) (Michelmore et al., 2017); Dark Lollo Rossa was found to be resistant in our initial screenings, romaine breeding line 60182 was found to be partially resistant (PR), and the iceberg commercial cultivar Chosen was found to be susceptible (S) (Supplemental Table 4).

UF/IFAS germplasm initial screening. Two additional ABD experiments (GH-6 and Field 7) were planted to screen 80 cultivars and breeding lines from the UF/IFAS germplasm (Table 1; Supplemental Table 3). GH-6 was planted in a greenhouse at EREC using 'Salinas' (PR), 60182 (PR), and 'Chosen' (S) (replicated nine times) as controls (Supplemental Table 4). Field 7 was conducted in the same $\mathrm{Fol}$-infested plot previously described and following the same planting and maintenance protocols. Breeding line 60182 (PR) and 'Chosen' (S) were replicated six times, whereas 'Dark Lollo Rossa' (R) was replicated four times and 'Lolla Rossa' (R) twice as controls (Supplemental Table 4).

Resistant confirmation. All germplasms that showed the highest levels of resistance in experiments 1 through 7 were retested in one greenhouse and two field experiments: Expt. GH-8 in the EREC greenhouse and Expts. Field 9.1 and 9.2 in the same Fol-infested field plot used in prior experiments. Fourteen wildtypes and PIs, 11 UF/IFAS breeding lines, and five commercial cultivars were tested in an RCBD with three replications alongside the controls 'Chosen' (S) and 'Dark Lolla Rossa' (R) (Supplemental Table 4). GH-8 contained five plants per replicate, whereas the plots in Field 9.1 and 9.2 typically contained $\approx 20$ plants per replicate.

Segregation analysis. Before these experiments, crosses between resistant $\times$ susceptible and partial resistant $\times$ susceptible accessions were made in greenhouse following a wellestablished protocol for crossing lettuce (Ryder, 1999). The $F_{1}$ hybrid was then planted to selfpollinate and produce the $\mathrm{F}_{2}$ seeds used in this study. Three hundred $\mathrm{F}_{2}$ disease-free seeds from population 'Dark Lollo Rossa $(\mathrm{R}) \times \mathrm{PI}$ 358001-1 (S)' and '60182 (PR) × PI 358001-1 (S)' were planted in 200-cell seeding trays, as well as 30 seeds of each of the parents from these populations and grown for $30 \mathrm{~d}$ before inoculation.

\section{Seedling preparation and inoculation protocol for greenhouse experiments}

The same inoculation protocol was used for greenhouse Expts. GH-4, GH-5, GH-6, and GH-8. Two lettuce seeds per cell were planted in 200-cell seeding trays containing sterilized potting soil (Sungro Horticulture, Agawam, MD). Emerging seedlings were thinned to one plant per cell, watered daily, and fertilized weekly for $30 \mathrm{~d}$ before inoculation. Plants were inoculated with the monoconidic EAA isolate $\mathrm{Fol} \# 51$ previously verified for high virulence (Murray et al., 2020). 


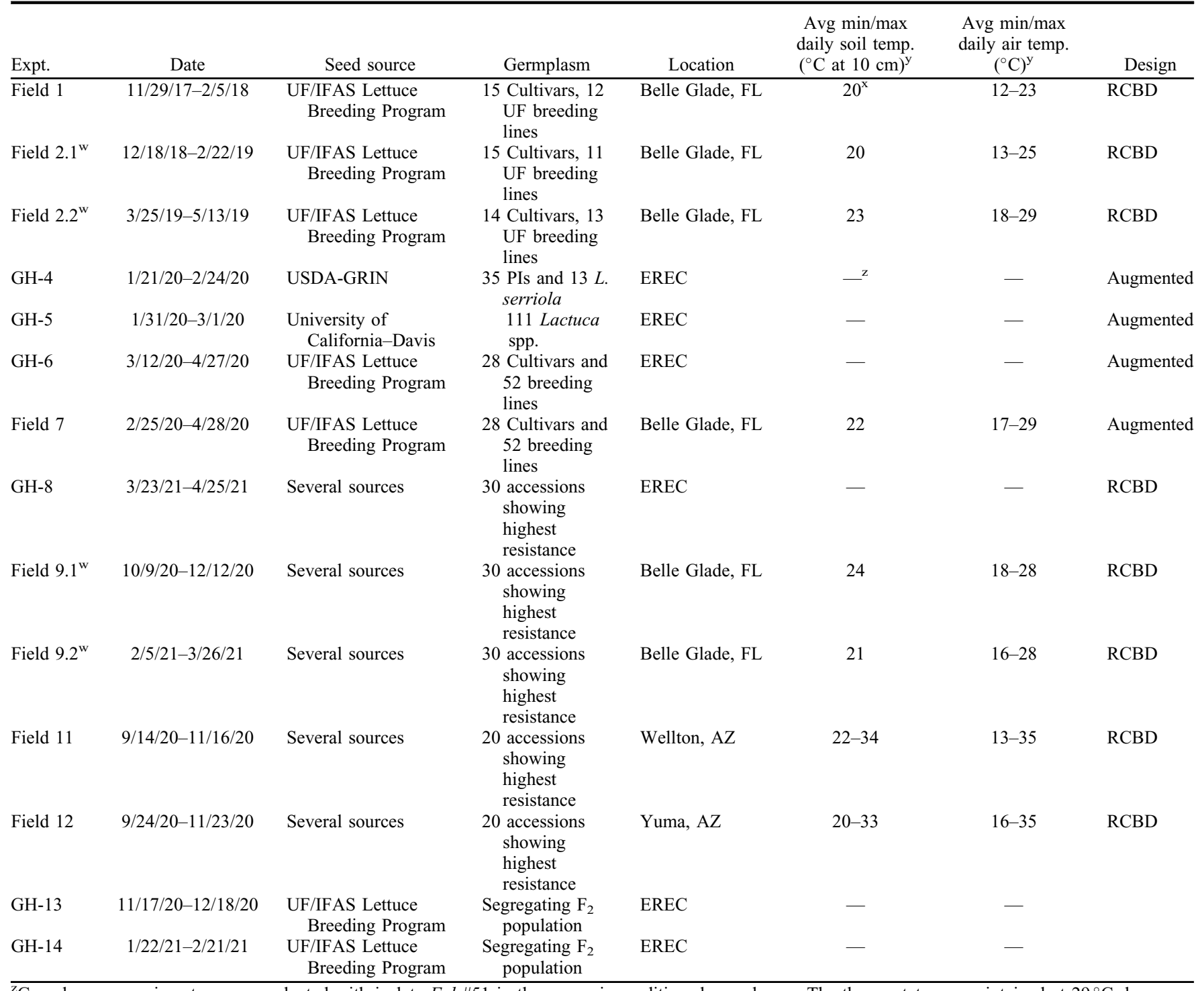

${ }^{\mathrm{z}}$ Greenhouse experiments were conducted with isolate $\mathrm{Fol} \# 51$ in the same air-conditioned greenhouse. The thermostat was maintained at $29^{\circ} \mathrm{C}$; however, daily minimum and maximum temperatures were not recorded inside the greenhouse during these trials.

${ }^{\mathrm{y}}$ University of Arizona, 2021; University of Florida, 2021.

${ }^{\mathrm{x}}$ Average daily minimum and maximum soil temperatures for Belle Glade field experiments typically varied by $<1{ }^{\circ} \mathrm{C}$; therefore, daily average temperature is reported.

${ }^{\mathrm{w}}$ Duplicate field experiments containing similar cultivars and experimental design conducted in an Everglades Agricultural Area field naturally infested with $\mathrm{Fol}$ race 1.

EREC $=$ Everglades Research and Education Center; UF = University of Florida; UF/IFAS = University of Florida Institute of Food and Agricultural Sciences.

Twelve days before inoculation, isolate $\mathrm{Fol} \# 51$ was grown on plates of potato dextrose agar (Difco Laboratories, Detroit, MI) for 1 week to obtain mycelia. Five days before inoculation, a plug of Fol \#51 mycelia was placed in sterile 100-ml potato dextrose broth (PDB; Difco Laboratories) and maintained at room temperature on a G10 Gyrotory Shaker (New Brunswick Scientific Co., Edison, NJ) set to $130 \mathrm{rpm}$ for 5 d. On the day of inoculation, the PDB cultures were filtered through four layers of sterilized cheese cloth and the suspensions were standardized to $1 \times 10^{6} \mathrm{~mL}^{-1}$ conidia using a Petroff-Hauser E60512-20 counting chamber (Hausser Scientific, Horscham, PA).
During inoculation, 30-d-old seedlings at approximately the four-leaf stage were removed from the trays without disrupting the roots. Untrimmed roots of all five seedlings for each accession were submerged and agitated in 200 $\mathrm{mL}$ of the conidial suspension for $\approx 15 \mathrm{~s}$ and then individually transplanted in separate $10-\mathrm{cm}$ plastic pots containing a $1: 1$ potting soil/sand mixture (Sungro Horticulture). The substrate was previously sterilized in an SST-15 soil sterilizer (All-American Associates, Mason City, IL) at $93^{\circ} \mathrm{C}$ for $48 \mathrm{~h}$ and maintained in a closed container before inoculations (Gilardi et al., 2017a). Each accession was submerged in a new batch of conidial suspension to avoid contamination. Five seedlings of control plants were mock inoculated by submerging their roots for $15 \mathrm{~s}$ in sterile deionized water and transplanted in separate plots as previously described (Supplemental Table 4). Plants were kept in a greenhouse dedicated to $\mathrm{Fol}$ screening, monitored, and watered daily until evaluation.

Segregation analysis. Fol conidia suspensions from $\mathrm{Fol} \# 51$ were grown as previously described $5 \mathrm{~d}$ before inoculation and used to inoculate $300 \mathrm{~F}_{2}$ seedlings from each population. Twenty plants of each parent were inoculated with Fol \#51 as a positive control, and 10 were mock inoculated for negative control. All plants were 
grown for $30 \mathrm{~d}$ in a greenhouse until evaluation.

\section{Disease ratings}

Field screenings. Disease ratings for Expts. Field 1 and Field 2.1 and 2.2 were taken at $30 \mathrm{~d}$ postplanting and at market maturity $60 \mathrm{~d}$ postplanting. Foliar disease severity (FDS) was measured on a 0 to 5 scale, where $0=$ no foliar symptoms; 1 = slight stunting and/or chlorosis; $2=$ moderate stunting and/or chlorosis; $3=$ wilting, moderate stunting/chlorosis; $4=$ severe wilting, stunting, and chlorosis; $5=$ plant dead (Fang et al., 2012). Foliar disease incidence (FDI) was calculated as the percentage of plants showing foliar symptoms per plot.

In Expts. Field 7 and Field 9.1 and 9.2, plants were rated for foliar symptoms at $30 \mathrm{~d}$ postplanting using the previously described scale. At $60 \mathrm{~d}$ postplanting, taproots were excavated from the soil, dissected longitudinally to reveal vascular tissue, and rated for root discoloration severity (RDS) using a 0 to 5 scale, where $0=$ no discoloration, $1=$ slight vascular discoloration, 2 = reddish-brown discoloration, 3 = severe discoloration and beginning necrosis, $4=$ severe discoloration and necrosis, and $5=$ plant dead (Fang et al., 2012). The root discoloration incidence (RDI) was calculated as the percentage of taproots displaying disease symptoms in each plot.

Greenhouse screenings. Asymptomatic plants dying within 1 to $5 \mathrm{~d}$ after inoculation were discarded as transplant errors in Expts. GH-4, GH-5, GH-6, and GH-8. Ratings for taproot discoloration occurred at weekly intervals as the accessions started to develop moderate foliar wilting symptoms, except for occasions when accessions were evaluated when bolted. The taproots of all five plants within each plot visually displaying foliar symptoms or bolting were dissected to record RDI and RDS using the same scale described earlier. The remaining plots without foliar symptoms or bolting were evaluated for RDI and RDS at $30 \mathrm{~d}$ postinoculation.

In Expts. GH-4, GH-5, and GH-6, asymptomatic taproots were surface disinfected in $10 \%$ sodium hypochlorite in a laminar hood for $10 \mathrm{~s}$, rinsed twice in sterile deionized water, allowed to partially dry on autoclaved paper towels, and implanted directly in Komada's semiselective medium to determine whether the pathogen was present in taproot vascular tissue (Komada, 1975). The percentage of taproots with positive $\mathrm{Fol}$ identification from the semiselective medium was used to calculate a corrected root discoloration incidence (RDIC), so that the final RDIC was the percentage of taproots displaying discoloration plus the percentage of asymptomatic taproots with positive $\mathrm{Fol}$ identification on Komada's Medium.

Segregation analysis. Plants showing moderate foliar symptoms of fusarium wilt were rated for disease incidence and severity using the 0 to 5 scale of taproot vascular discoloration previously described, and all remaining plants were rated for taproot discoloration at $30 \mathrm{~d}$ post-Fol inoculation.

\section{Data analysis}

The foliar and root DI, DIC, and DS were analyzed as an RCBD in Expts. Field 1, Fields 2.1 and 2.2, GH-8, Fields 9.1 and 9.2, Field 11, and Field 12 (Table 1). The analysis of variance (ANOVA) was obtained using nonparametric statistic with ranked methods. The analysis was conducted in PROC MIXED of SAS Institute Version 9.4. (2019; Cary, NC). In the ANOVA, replicates were nested to the experiment and accessions were used as the repeated statement. Relative marginal effects (RMEs) and confidence intervals (CIs) at $95 \%$ probability were calculated using the macro LD_CI generated in PROC IML of SAS Institute Version 9.4. (Shah and Madden, 2004).

The foliar and root DI, DIC, and DS were analyzed as an augmented design in Expts. GH-4, GH-5, GH-6, and Field 7. An ANOVA using PROC MIXED of SAS software Version 9.4. was computed. In the ANOVA, blocks were considered as random effects, and the newly tested accessions and controls were considered as fixed effects. To test differences between the newly tested accessions and each of the controls, a Dunnett two-tailed $t$ test was performed between the tested accessions and resistant and susceptible controls.

The number of observed and expected resistant and susceptible plants for each segregating $\mathrm{F}_{2}$ population were used to calculate a chi-square test $(P=0.05)$ to determine whether the observed results fit the expected ratios based on the inheritance of either one dominant gene (3 Resistant: 1 Susceptible) or one recessive gene (3 Susceptible: 1 Resistant).

\section{Results and Discussion}

\section{Initial screening of Florida-adapted germplasm}

Fusarium wilt of lettuce was first detected in Florida in 2017 and has been confirmed as race 1 within a small, localized region (Murray et al., 2020). The pathogen has persisted in initial fields, and newer detections have occurred in surrounding plots when planted with Fol susceptible cultivars. Due to the long-term persistence of $\mathrm{Fol}$, it was imperative to first identify genetic resistance in cultivars adapted to growing conditions in South Florida. An initial field experiment (Field 1) from Winter 2017 indicated significant differences $(P=0.0004)$ for FDI and FDS among the tested accessions (Table 2). None of the commercial cultivars currently planted by growers in Florida or previously released cultivars from UF/IFAS had complete resistance to Fol race 1 in this experiment. The commercial cultivars Manatee, Homestead, and RSX743; the UF/IFAS cultivars Floribibb, Floricos 83, Floricrisp 1265, and Terrapin; and UF/IFAS breeding lines 60176 and 60182 did have low levels of FDI and FDS in this first assessment (Table 3). Similar to previous studies, iceberg cultivars had greater overall FDI and FDS compared with romaine cultivars (Table 3) (Matheron et al., 2005;

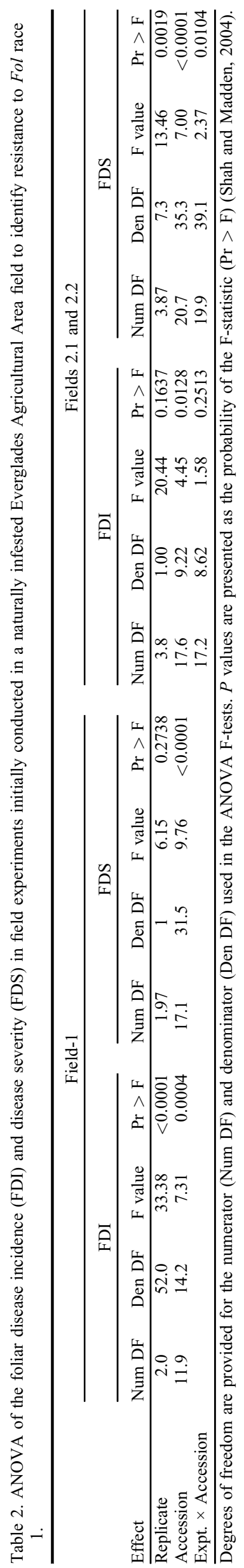


Table 3. Relative marginal effects (RME), lower and upper confidence intervals for foliar disease incidence (FDI) and disease severity (FDS) in an initial screening Expt. Field 1 of lettuce cultivars and lines in an Everglades Agricultural Area field naturally infested with Fol race 1.

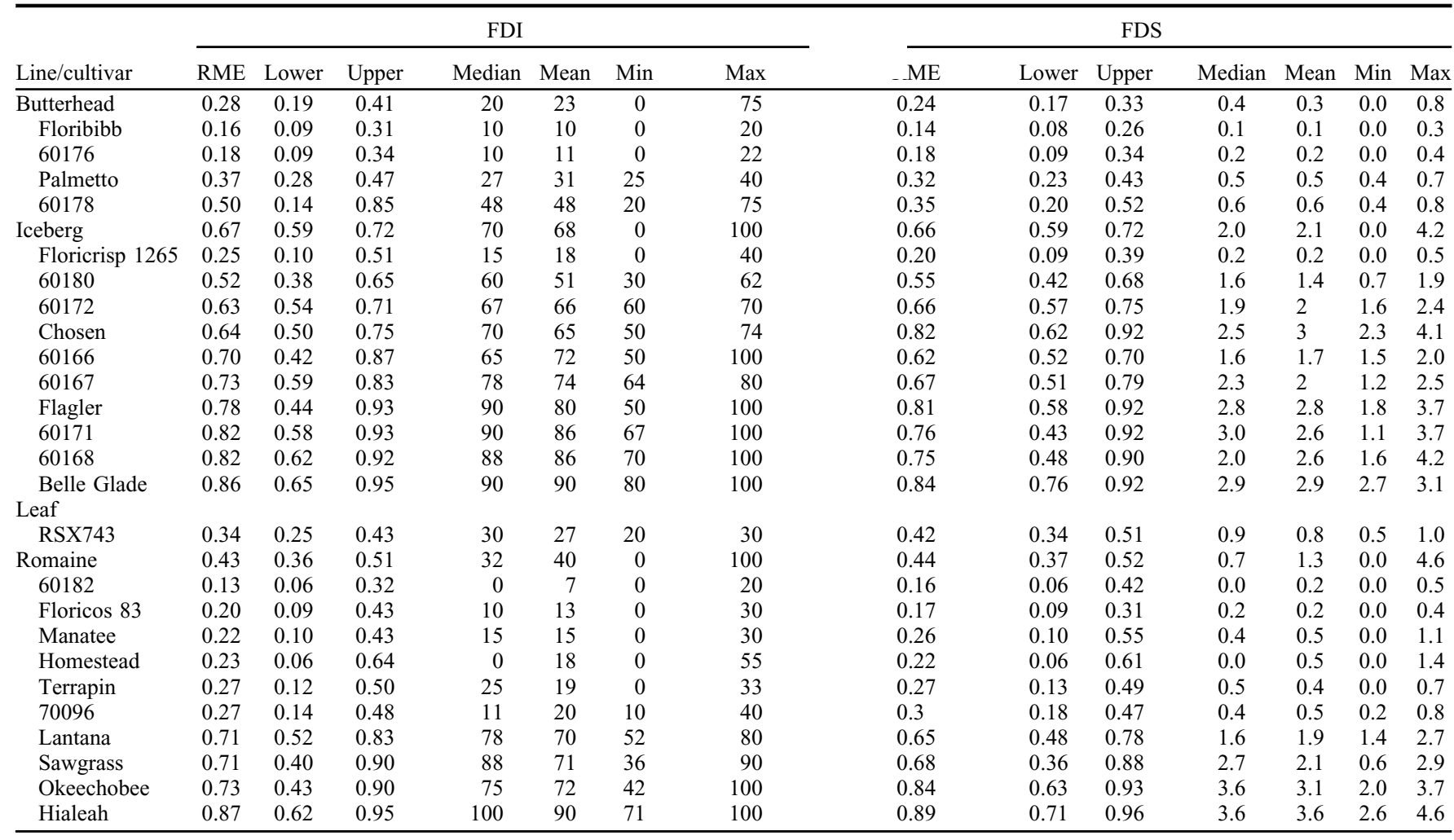

Scott et al., 2010b). Butterhead cultivars had the lowest overall FDI and FDS and Fol resistance has not yet been extensively reported for this lettuce type.

Cultivars Floribibb and Floricos 83, as well as breeding line 60182 , have the romaine cultivar Valmaine as a parent in their pedigree. 'Valmaine' has previously been described as resistant to Fol race 1 (Michelmore et al., 2017) and may contribute resistance alleles to these genotypes. Additionally, 'Floribibb' has 'Calmar' in its pedigree, which McCreight et al. (2005) found to be resistant to Fol race 1 in Arizona. Future segregation or QTL analyses could ascertain whether 'Valmaine' or 'Calmar' have donated resistance alleles to cultivars and lines in this study or any of their other contemporary progeny. Crossing accessions with 'Valmaine' and 'Calmar' in their pedigree could be useful in developing Florida-adapted germplasm with transgressive resistance loci.

Two additional experiments were planted in the same field, one in Winter 2018 and the second in Spring 2019 to verify results on Florida-adapted accessions and identify resistance in additional tested accessions. Significant differences in FDI and FDS $(P=0.0128$ and $P<0.0001$, respectively) were found among the accessions (Table 2). No Floridaadapted germplasm was resistant to the pathogen; however, breeding line 60182 and cultivar Floricrisp 1265 continued to exhibit low FDI and FDS (Table 4). The UF/IFAS cultivar Tall Guzmaine and cultivars not adapted to Florida Green Towers, Valmaine, Salinas, and Lolla Rossa had low levels of FDI and
FDS (Table 4). The resistance displayed by cultivars Green Towers, Valmaine, Salinas, and Lolla Rossa agree with previous screening results for $\mathrm{Fol}$ race 1 (Matheron et al., 2005; Scott et al., 2010b, 2012, 2014). Romaine and leaf cultivars continued to show lower FDI and FDS than iceberg cultivars; however, butterhead cultivars had greater FDI and FDS during these trials (Table 4).

\section{Relationship between foliar wilting symptoms and taproot colonization}

Identifying genotypes resistant to $\mathrm{Fol}$ race 1 based on the absence of foliar symptoms helps fast-track breeding solutions for reducing damage caused by this pathogen, but evaluating taproot colonization should be considered for long-term protection. $\mathrm{Fol}$ has been documented to extensively colonize the taproots of lettuce that does not display foliar symptoms, allowing the pathogen to continue proliferating in infested soils (Gordon and Koike, 2015). Identifying genotypes with no foliar symptoms and the least taproot colonization may help avoid increasing $\mathrm{Fol}$ inoculum in infested soils.

Significant differences in RDI and RDS ( $P<0.0001$, respectively) were observed among the tested accessions for Expts. GH-4 and GH-5 in plants inoculated with the isolate Fol \#51 (Table 5). RDIC was measured by observing Fol colony formation of taproot sections plated on Komada's medium. In GH-4, only PI 165063 had RDI and RDIC of 0\% (Supplemental Table 5). Additionally, PI 220665 and PI 615055 showed no taproot discoloration and had RDIC of $20 \%$, which was significantly less colonized than susceptible check 'Chosen' (Supplemental Table 5). The abovementioned PIs and PI 164940 were selected for future resistance confirmation experiments. Five L. serriola accessions in Expt. GH-5 had RDI and RDIC of $0 \%$ (Supplemental Table 6). An additional five $L$. serriola accessions had no taproot discoloration and RDIC of $20 \%$ when plated on Komada's medium, which was significantly less colonized than 'Chosen' (Supplemental Table 6). Similarly, these $10 \mathrm{~L}$. serriola accessions were selected for future experiments.

Expts. GH-6 and Field 7 in Spring 2020 (Table 1) were conducted to evaluate additional Florida-adapted germplasm for taproot vascular discoloration. Significant differences in RDI were detected among tested accessions for both experiments $(P=0.0002$ in GH-6 and $P<$ 0.0001 in Field 7; Table 5). No root discoloration was observed in breeding line 60182, 'Costa Rica \#4', 'Floribibb', 'Floricrisp 1265', and 'Terrapin' when inoculated with Fol \#51 in the greenhouse experiment; however, only 'Costa Rica \#4' and 'Floribibb' had RDIC of 0\% (Supplemental Table 7). The breeding lines 47083, 49530, 49889, 50100, and 60168, as well as cultivar Galactic, had RDI and RDIC of $0 \%$ (Supplemental Table 7). In a similar study, cultivars King Henry, Caesar, Red Rossa, Lolla Rossa, and Green Forest were asymptomatic when rated for Fol foliar symptoms but $\mathrm{Fol}$ isolation rates from taproots remained high when whole sections of individual taproot tissues were homogenized and plated by serial dilution on Komada's medium (Scott et al., 2014). 
Table 4. Relative marginal effects (RME), lower and upper confidence intervals for foliar disease incidence (FDI) and severity (FDS) in an initial screening Expt. Field 2.1 and 2.2 of lettuce cultivars and lines in an Everglades Agricultural Area field naturally infested with $F o l$ race 1.

\begin{tabular}{|c|c|c|c|c|c|c|c|c|c|c|c|c|c|c|}
\hline Line/cultivar & \multicolumn{7}{|c|}{ FDI } & \multicolumn{7}{|c|}{ FDS } \\
\hline Butterhead & 0.66 & 0.57 & 0.74 & 100 & 88 & 0 & 100 & 0.49 & 0.40 & 0.57 & 3.0 & 2.5 & 0.0 & 4.0 \\
\hline Floribibb & 0.49 & 0.23 & 0.75 & 100 & 60 & 0 & 100 & 0.37 & 0.18 & 0.62 & 2.0 & 1.7 & 0.0 & 3.5 \\
\hline Palmetto & 0.74 & 0.70 & 0.77 & 100 & 100 & 100 & 100 & 0.50 & 0.37 & 0.63 & 3.0 & 2.6 & 1.0 & 3.0 \\
\hline 60178 & 0.74 & 0.70 & 0.77 & 100 & 100 & 100 & 100 & 0.53 & 0.44 & 0.62 & 3.0 & 2.8 & 2.0 & 3.0 \\
\hline Iceberg & 0.55 & 0.50 & 0.60 & 100 & 70 & 0 & 100 & 0.60 & 0.54 & 0.65 & 3.0 & 2.9 & 0.0 & 5.0 \\
\hline 60168 & 0.47 & 0.26 & 0.69 & 62 & 55 & 0 & 100 & 0.56 & 0.32 & 0.77 & 3.3 & 2.6 & 0.0 & 4.0 \\
\hline Chosen & 0.51 & 0.28 & 0.74 & 61 & 61 & 20 & 100 & 0.60 & 0.30 & 0.84 & 3.0 & 3.1 & 1.5 & 5.0 \\
\hline 60172 & 0.57 & 0.37 & 0.75 & 100 & 71 & 26 & 100 & 0.66 & 0.42 & 0.84 & 4.0 & 3.3 & 2.0 & 4.0 \\
\hline 60166 & 0.58 & 0.39 & 0.75 & 100 & 72 & 6 & 100 & 0.64 & 0.46 & 0.79 & 3.3 & 3.2 & 1.5 & 4.0 \\
\hline Belle Glade & 0.60 & 0.42 & 0.75 & 100 & 79 & 10 & 100 & 0.68 & 0.47 & 0.84 & 3.8 & 3.3 & 1.0 & 4.0 \\
\hline 60167 & 0.60 & 0.42 & 0.75 & 100 & 78 & 17 & 100 & 0.57 & 0.33 & 0.78 & 3.0 & 2.8 & 1.0 & 4.0 \\
\hline Flagler & 0.61 & 0.36 & 0.81 & 100 & 80 & 0 & 100 & 0.51 & 0.32 & 0.70 & 3.0 & 2.5 & 0.0 & 3.5 \\
\hline Lolla Rossa & 0.51 & 0.15 & 0.86 & 60 & 60 & 19 & 100 & 0.42 & 0.19 & 0.70 & 2.3 & 2.3 & 1.5 & 3.0 \\
\hline PI 358001-1 & 0.74 & 0.70 & 0.77 & 100 & 100 & 100 & 100 & 0.81 & 0.71 & 0.88 & 4.0 & 3.8 & 3.5 & 4.0 \\
\hline Red Tide & 0.74 & 0.70 & 0.77 & 100 & 100 & 100 & 100 & 0.60 & 0.16 & 0.92 & 3.0 & 3.0 & 2.0 & 4.0 \\
\hline Romaine & 0.41 & 0.37 & 0.46 & 50 & 50 & 0 & 100 & 0.44 & 0.39 & 0.48 & 2.5 & 2.0 & 0.0 & 5.0 \\
\hline Green Towers & 0.24 & 0.07 & 0.55 & 25 & 25 & 0 & 50 & 0.16 & 0.08 & 0.31 & 0.3 & 0.3 & 0.0 & 0.5 \\
\hline Hialeah & 0.32 & 0.07 & 0.75 & 0 & 33 & 0 & 100 & 0.40 & 0.06 & 0.87 & 0.0 & 1.7 & 0.0 & 5.0 \\
\hline Tall Guzmaine & 0.33 & 0.26 & 0.40 & 28 & 28 & 28 & 29 & 0.79 & 0.64 & 0.89 & 3.8 & 3.8 & 3.5 & 4.0 \\
\hline 60182 & 0.34 & 0.15 & 0.61 & 3 & 34 & 0 & 100 & 0.21 & 0.14 & 0.33 & 0.8 & 0.9 & 0.0 & 2.0 \\
\hline Okeechobee & 0.35 & 0.16 & 0.61 & 12 & 37 & 0 & 100 & 0.36 & 0.17 & 0.62 & 1.3 & 1.6 & 0.0 & 4.0 \\
\hline 60185 & 0.36 & 0.17 & 0.60 & 63 & 46 & 0 & 100 & 0.29 & 0.16 & 0.48 & 2.0 & 1.4 & 0.0 & 3.0 \\
\hline 43007 & 0.37 & 0.18 & 0.61 & 15 & 38 & 0 & 100 & 0.41 & 0.22 & 0.64 & 2.5 & 2.0 & 0.0 & 4.0 \\
\hline Sawgrass & 0.41 & 0.19 & 0.68 & 48 & 50 & 0 & 100 & 0.36 & 0.16 & 0.64 & 2.0 & 1.7 & 0.0 & 4.0 \\
\hline Manatee & 0.41 & 0.20 & 0.66 & 63 & 56 & 0 & 100 & 0.70 & 0.27 & 0.93 & 4.0 & 3.3 & 0.0 & 5.0 \\
\hline
\end{tabular}

In the Field 7 experiment conducted in a naturally Fol-infested field, the nonadapted cultivars Dark Lollo Rossa, Costa Rica \#4, Galactic, and Red Rage exhibited no taproot vascular discoloration (Supplemental Table 8). The Florida-adapted cultivar Floribibb displayed a relatively low RDI of $17 \%$ (Supplemental Table 8). Florida breeding lines 43007, C1139, C1144, and C1145 had an RDI of $0 \%$. Additionally, each of these lines have Fol-resistant 'Valmaine' in their pedigree. On the basis of the results from these two experiments, 11 UF breeding lines and five nonadapted commercial cultivars to the Florida environment were selected for future confirmation experiments (Supplemental Tables 7 and 8).

Initially, minimal taproot colonization and foliar symptoms were identified in 30 accessions consisting of two butterheads, three icebergs, four leaf types, one leaf/romaine type, 10 romaines and 10 wildtypes. To maintain lettuce marketability and mitigate proliferation and spread of $\mathrm{Fol}$, it is recommended that $\mathrm{Fol}$ resistance selections be based on both plants with no above-ground symptoms and little to no root colonization (Scott et al., 2014). Incorporating these two measurements may assist with combining resistance alleles in new cultivars and improve resistance durability by

Table 5. ANOVA for the root disease incidence (RDI) and severity (RDS) of accessions tested in augmented design in greenhouse $\mathrm{e}^{\mathrm{z}}$ and field experiments.

\begin{tabular}{|c|c|c|c|c|c|c|c|c|c|}
\hline Expt. & Sources & \multicolumn{4}{|c|}{ RDI } & \multicolumn{4}{|c|}{ RDS } \\
\hline \multirow[t]{2}{*}{$\overline{\mathrm{GH}}-4$} & New entries & 51 & 15 & 6.58 & $<0.0001$ & 51 & 15 & 6.94 & $<0.0001$ \\
\hline & Controls & 4 & 15 & 29.59 & $<0.0001$ & 4 & 15 & 28.57 & $<0.0001$ \\
\hline GH-5 & Controls & 4 & 42 & 148.18 & $<0.0001$ & 4 & 42 & 263.69 & $<0.0001$ \\
\hline \multirow[t]{2}{*}{ GH-6 } & New entries & 80 & 18 & 5.06 & 0.0002 & 80 & 18 & 10.15 & $<0.0001$ \\
\hline & Controls & 3 & 18 & 46.09 & $<0.0001$ & 3 & 18 & 99.23 & $<0.0001$ \\
\hline
\end{tabular}

${ }^{2}$ Greenhouse experiments were conducted with isolate Fol \#51.

${ }^{\mathrm{y}}$ Field experiments were conducted in an EAA field naturally infested with $\mathrm{Fol}$ race 1.

Degrees of freedom are provided for the numerator (Num DF) and denominator (Den DF) used in the ANOVA F-tests. $P$-values are presented as the probability of the F-statistic $(\operatorname{Pr}>$ F) (Shah and Madden, 2004). 
preventing an increase in $\mathrm{Fol}$ inoculum in infested fields. Avoiding further increases of the pathogen is paramount for the Florida lettuce production system because Fol is still localized within a few plots in the EAA.

\section{Confirmation of taproot resistance in Florida}

Thirty Florida-adapted genotypes, PIs, and Lactuca wildtypes demonstrating highest resistance in the initial screening experiments were further evaluated in replicated RCBD greenhouse and infested field experiments (Table 1). The ANOVA for Expt. GH-8 showed significant differences for RDI and RDS among accessions $(P<0.0001$; Table 6$)$. In greenhouse experiments, only cultivar Dark Lollo Rossa was asymptomatic for root discoloration; however, its RMEs for RDI and RDS were not significantly different from 50100 and 60182 (Fig. 1). Breeding lines 43007, 47083, 49530, C1139, C1144, and C1145 had similarly low RMEs (Fig. 1) and the same median of RDI values $(20 \%)$ as partially resistant 60182 (Table 7).

Field experiments conducted in the same Fol-infested field showed significant differences for RDI and RDS among accessions ( $P=0.0149$ and $P<0.0001$, respectively $)$ between the two experiments $(P<0.0001)$ and for the Experiment $\times$ Accession interaction for RDS $(P<0.0001)$ (Table 6). In general, disease incidences and severities were higher in Expt. Field 9.1 conducted during the first planting, in which higher temperatures may have exacerbated $\mathrm{Fol}$ symptoms as previously reported (Table 1) (Matheron et al., 2005; Scott et al., 2010a). The cultivar Galactic was the only genotype that was nearly asymptomatic (Table 8). Romaine breeding lines 43007, 50100, and 60182 had median RDI of $0 \%$ and RDS of 0 , and C1144 had a RME that was not significantly different from 60182 (Table 8; Fig. 2). Iceberg breeding line 47083 continued to show low disease symptoms in Field 9.1 and 9.2. Across these resistance confirmation experiments, leaf and romaine cultivars performed similarly overall and exhibited the lowest RDI and RDS as in previous studies (Tables 7 and 8) (Matheron et al., 2005; Scott et al., 2010b). Butterhead and iceberg cultivars had slightly higher RDI and RDS overall, but the two types performed similar to each other as a group (Tables 7 and 8). Each of the wildtypes and PIs selected for these resistance confirmation experiments displayed much greater root discoloration incidence than in the initial experiments.

\section{Testing resistant Florida selections in highly Fol-infested Arizona fields}

Fusarium wilt has existed in the United States for decades since its discovery in the San Joaquin Valley of California in 1992 (Hubbard and Gerik, 1993) and Yuma, AZ, in 2002 (Matheron and Koike, 2003). Fol has been more difficult to avoid in Arizona due to its proliferation and because warmer temperatures increase the susceptibility of lettuce to this pathogen, especially during the first planting slot in September (Matheron et al., 2005; Scott et al., 2010a). Test plots with natural $\mathrm{Fol}$ infestation and high disease pressure have been used for screening lettuce in Yuma County since 2015. Other crops are planted in these test sites between lettuce screening experiments, yet high pathogen inoculum persists (S. Slinski, personal communication). These sites in Wellton and Yuma, AZ, were used in experiments Field 11 and Field 12, respectively, to further validate resistance in the initial Florida experiments (Table 1).

Foliar disease incidences were significantly different among accessions in Field 11 and Field $12(P=0.0075$ and $P=0.0107$, respectively; Table 9). In both experiments, the susceptible check El Guapo showed consistently high FDS and FDI, whereas the resistant control Meridian showed less FDI and FDS (Fig. 3; Tables 10 and 11). Romaine breeding lines 43007, 50100, 60182, C1144, and $\mathrm{C} 1145$; iceberg breeding line 47083 ; and leaf cultivars Dark Lollo Rossa and Galactic showed low FDI and FDS in both Field 11 and Field 12 (Fig. 3; Tables 10 and 11). This result was consistent with their low RDI and RDS in the Florida screening experiments. Additionally, romaine breeding line 49530, romaine cultivars Red Rage and Terrapin, and bibb cultivar Floribibb showed low FDI and FDS in the Arizona trials. Similar to the taproot confirmation experiments, leaf and romaine types as a group had the lowest FDI and FDS (Tables 10 and 11). This was followed by butterhead genotypes, which had lower foliar symptoms than iceberg genotypes (Tables 10 and 11). Poor germination among wildtypes and some PIs made it difficult to draw conclusions regarding foliar symptoms in these experiments; however, the leaf type PI 615055 displayed low foliar symptoms in both Fields 11 and 12. Although some of these latter genotypes may not possess the same level of taproot resistance to Fol, they may still have resistance alleles that permit relatively few foliar symptoms and may be considered for future breeding programs or genetic studies.

\section{Segregation analysis}

Two $F_{2}$ populations segregating for resistance to Fol race 1 'Dark Lollo Rossa $\times$ PI 358001-1' and '60182 × PI 358001-1' were screened for taproot discoloration with virulent isolate $\mathrm{Fol} \# 51$ in greenhouse experiments (GH-13 and GH-14; Table 1). The parent 'Dark Lollo Rossa' had 18 plants with no root discoloration and four plants with mild symptoms (ratings of $\leq 2$ ), and PI 358001-1 had three plants with no root discoloration and 18 plants with severe symptoms (Table 12). The observed resistant-to-susceptible ratio for the $\mathrm{F}_{2}$ population from 'Dark Lollo Rossa $\times$ PI 358001-1' was 132:199, which deviated from the expected ratio $(P<0.0001)$ for both single recessive and single dominant models (Table 12). This suggests that multiple alleles may confer resistance in 'Dark Lollo Rossa' (Table 12). The parent 60182 
had 15 plants without root discoloration and eight plants with mild symptoms, and PI 358001-1 had four plants without root discoloration and 20 with severe symptoms (Table 12). The ratio of resistant: susceptible $\mathrm{F}_{2}$ plants from '60182 × PI 358001-1' was 61:235, which did not deviate from the expected model of inheritance of a single recessive allele ( $P=$ 0.0812; Table 12).

McCreight et al. (2005) found evidence for the simple inheritance of a recessive allele from 'Salinas' in their segregation analysis of an $F_{2}$ population from 'Vanguard $\times$ Salinas'. 'Salinas' is considered partially resistant to Fol race 1 and 60182 can be considered as partially resistant (Table 12). Although the exact number of loci involved in the resistance response for 'Dark Lollo Rosso' and 60182 remains undetermined, the proportion of resistant $\mathrm{F}_{2}$ plants in 'Dark Lollo Rossa $\times$ PI 358001-1' population was roughly twice that of ' $60182 \times$ PI 358001-1' population. This may signify the potential for combining different sources of vertical and horizontal resistance in one genotype by crossing 'Dark Lollo Rossa $\times 60182$ '. This cross combination could result in greater taproot resistance to Fol, in addition to longer durability of resistance in highly infested regions.

\section{Conclusions}

In this study, a combination of foliar and taproot disease ratings was used to help identify germplasm that is resistant to Fol. The genotypes displaying consistently low foliar and taproot symptoms to $\mathrm{Fol}$ race 1 across all experiments and locations in this study were
Table 7. Root discoloration incidence (RDI) and discoloration severity (RDS) dispersion measurements of 28 Lactuca accessions tested in Expt. GH-8 at the Everglades Research and Education Center, Belle Glade, FL.

\begin{tabular}{|c|c|c|c|c|c|c|c|c|c|c|}
\hline \multirow[b]{2}{*}{ Accession } & \multicolumn{5}{|c|}{ RDI } & \multicolumn{5}{|c|}{ RDS } \\
\hline & Median & Mean & Min & Max & $\mathrm{N}$ & Median & Mean & Min & Max & $\mathrm{N}$ \\
\hline Butterhead & 30 & 33.3 & 20 & 60 & 6 & 0 & 0.6 & 0 & 2 & 30 \\
\hline 49530 & 20 & 26.7 & 20 & 40 & 3 & 0 & 0.5 & 0 & 2 & 15 \\
\hline Floribibb & 40 & 40.0 & 20 & 60 & 3 & 0 & 0.8 & 0 & 2 & 15 \\
\hline Iceberg & 30 & 26.0 & 0 & 60 & 10 & 0 & 0.5 & 0 & 2 & 50 \\
\hline 47083 & 20 & 24.0 & 0 & 60 & 5 & 0 & 0.4 & 0 & 2 & 25 \\
\hline 49889 & 30 & 30.0 & 20 & 40 & 2 & 0 & 0.6 & 0 & 2 & 10 \\
\hline 60168 & 40 & 26.7 & 0 & 40 & 3 & 0 & 0.5 & 0 & 2 & 15 \\
\hline Leaf & 0 & 24.0 & 0 & 80 & 5 & 0 & 0.5 & 0 & 2 & 25 \\
\hline Dark Lollo Rossa & 0 & 0.0 & 0 & 0 & 2 & 0 & 0.0 & 0 & 0 & 10 \\
\hline Red Rage & 40 & 40.0 & 0 & 80 & 3 & 0 & 0.8 & 0 & 3 & 15 \\
\hline \multicolumn{11}{|l|}{ Leaf/Romaine } \\
\hline PI 165063 & 100 & 93.3 & 80 & 100 & 3 & 2 & 2.1 & 0 & 5 & 14 \\
\hline Romaine & 20 & 31.3 & 0 & 100 & 40 & 0 & 0.5 & 0 & 2 & 196 \\
\hline 50100 & 0 & 4.0 & 0 & 20 & 5 & 0 & 0.1 & 0 & 2 & 25 \\
\hline 60182 & 20 & 12.0 & 0 & 20 & 5 & 0 & 0.2 & 0 & 2 & 25 \\
\hline $\mathrm{C} 1144$ & 20 & 20.0 & 0 & 40 & 5 & 0 & 0.4 & 0 & 2 & 25 \\
\hline $\mathrm{C} 1145$ & 20 & 24.0 & 0 & 60 & 5 & 0 & 0.4 & 0 & 2 & 25 \\
\hline C1139 & 20 & 26.7 & 20 & 40 & 3 & 0 & 0.4 & 0 & 2 & 15 \\
\hline 43007 & 20 & 26.7 & 20 & 40 & 3 & 0 & 0.4 & 0 & 2 & 15 \\
\hline Terrapin & 40 & 33.3 & 20 & 40 & 3 & 0 & 0.5 & 0 & 2 & 15 \\
\hline 50098 & 40 & 36.0 & 0 & 60 & 5 & 0 & 0.5 & 0 & 2 & 25 \\
\hline PI 220665 & 80 & 66.7 & 40 & 80 & 3 & 1 & 1.1 & 0 & 2 & 15 \\
\hline PI 164940 & 100 & 100.0 & 100 & 100 & 3 & 2 & 2.0 & 2 & 2 & 11 \\
\hline Wildtypes & 60 & 69.2 & 20 & 100 & 30 & 2 & 1.7 & 0 & 5 & 147 \\
\hline Azer16-50818 & 40 & 40.0 & 20 & 60 & 3 & 0 & 0.7 & 0 & 3 & 15 \\
\hline Azer16-50809 & 40 & 51.7 & 40 & 75 & 3 & 1 & 1.1 & 0 & 3 & 14 \\
\hline Azer16-50833 & 60 & 53.3 & 40 & 60 & 3 & 2 & 1.9 & 0 & 5 & 15 \\
\hline Azer16-50824 & 60 & 60.0 & 20 & 100 & 3 & 2 & 1.3 & 0 & 3 & 15 \\
\hline Azer16-50805 & 60 & 60.0 & 40 & 80 & 3 & 2 & 1.7 & 0 & 5 & 15 \\
\hline W6 47289 & 60 & 60.0 & 60 & 60 & 3 & 2 & 1.3 & 0 & 3 & 15 \\
\hline Azer16-50865 & 80 & 73.3 & 40 & 100 & 3 & 1 & 1.3 & 0 & 3 & 15 \\
\hline Azer16-50803 & 100 & 93.3 & 80 & 100 & 3 & 3 & 3.1 & 0 & 5 & 15 \\
\hline Azer16-50793 & 100 & 100.0 & 100 & 100 & 3 & 2 & 1.9 & 1 & 2 & 13 \\
\hline W6 40649 & 100 & 100.0 & 100 & 100 & 3 & 3 & 2.6 & 1 & 4 & 15 \\
\hline \multicolumn{11}{|l|}{ Susceptible control } \\
\hline Chosen & 100 & 100.0 & 100 & 100 & 3 & 3 & 2.9 & 1 & 5 & 15 \\
\hline
\end{tabular}

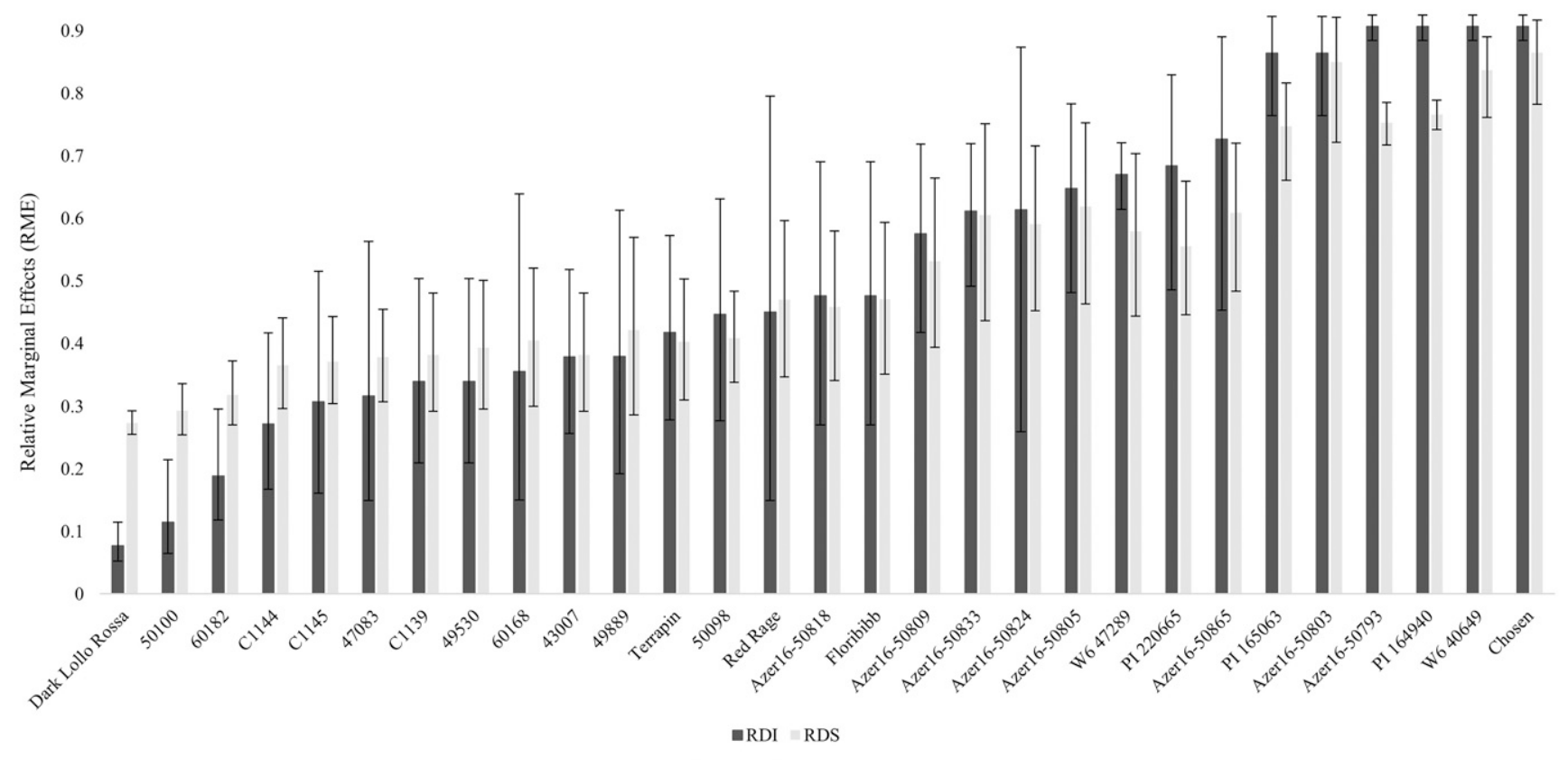

Fig. 1. Relative marginal effects (RME) for the root discoloration incidence (RDI) and severity (RDS) of accessions tested in GH-8 with inoculation of isolate $\mathrm{Fol} \# 51$. Error bars represent confidence intervals at $95 \%$. 
Table 8. Root discoloration incidence (RDI) and discoloration severity (RDS) dispersion measurements of 28 Lactuca accessions tested in Expts. Field 9.1 and Field 9.2 near Belle Glade, FL.

\begin{tabular}{|c|c|c|c|c|c|c|c|c|c|c|}
\hline \multirow[b]{2}{*}{ Accession } & \multicolumn{5}{|c|}{ RDI } & \multicolumn{5}{|c|}{ RDS } \\
\hline & Median & Mean & Min & Max & $\mathrm{N}$ & Median & Mean & Min & Max & $\mathrm{N}$ \\
\hline Butterhead & 11.4 & 20.7 & 0.0 & 66.7 & 12 & 0.0 & 0.3 & 0.0 & 3.0 & 221 \\
\hline 49530 & 11.4 & 15.3 & 0.0 & 36.0 & 6 & 0.0 & 0.2 & 0.0 & 3.0 & 124 \\
\hline Floribibb & 18.1 & 26.1 & 0.0 & 66.7 & 6 & 0.0 & 0.4 & 0.0 & 2.0 & 97 \\
\hline Iceberg & 11.4 & 20.4 & 0.0 & 68.2 & 20 & 0.0 & 0.4 & 0 & 3.0 & 337 \\
\hline 47083 & 0.0 & 6.1 & 0.0 & 26.7 & 8 & 0.0 & 0.1 & 0.0 & 1.0 & 143 \\
\hline 60168 & 30.1 & 27.0 & 0.0 & 55.6 & 6 & 0.0 & 0.4 & 0.0 & 2.0 & 77 \\
\hline 49889 & 30.9 & 33.0 & 0.0 & 68.2 & 6 & 0.0 & 0.7 & 0.0 & 3.0 & 117 \\
\hline Leaf & 13.3 & 17.0 & 0.0 & 57.1 & 19 & 0.0 & 0.2 & 0.0 & 3.0 & 372 \\
\hline Galactic & 0.0 & 2.0 & 0.0 & 5.9 & 3 & 0.0 & 0.0 & 0.0 & 1.0 & 49 \\
\hline Red Rage & 9.8 & 17.2 & 0.0 & 42.9 & 6 & 0.0 & 0.4 & 0.0 & 3.0 & 104 \\
\hline Dark Lollo Rossa & 20.4 & 17.4 & 0.0 & 42.9 & 8 & 0.0 & 0.2 & 0.0 & 2.0 & 206 \\
\hline PI 615055 & 36.9 & 36.9 & 16.7 & 57.1 & 2 & 0.0 & 0.4 & 0.0 & 1.0 & 13 \\
\hline Romaine & 9.7 & 12.2 & 0.0 & 42.1 & 54 & 0.0 & 0.2 & 0.0 & 3.0 & 949 \\
\hline 50100 & 0.0 & 4.1 & 0.0 & 14.3 & 7 & 0.0 & 0.1 & 0.0 & 2.0 & 151 \\
\hline 60182 & 0.0 & 11.3 & 0.0 & 31.3 & 5 & 0.0 & 0.2 & 0.0 & 1.0 & 68 \\
\hline C1144 & 3.8 & 8.8 & 0.0 & 32.1 & 8 & 0.0 & 0.1 & 0.0 & 2.0 & 202 \\
\hline 43007 & 6.0 & 13.7 & 0.0 & 35.3 & 6 & 0.0 & 0.2 & 0.0 & 2.0 & 106 \\
\hline 50098 & 11.1 & 10.7 & 0.0 & 23.5 & 7 & 0.0 & 0.2 & 0.0 & 2.0 & 79 \\
\hline Terrapin & 15.0 & 15.8 & 0.0 & 33.3 & 6 & 0.0 & 0.2 & 0.0 & 2.0 & 87 \\
\hline C1139 & 15.6 & 15.7 & 0.0 & 35.1 & 6 & 0.0 & 0.2 & 0.0 & 3.0 & 121 \\
\hline PI 220665 & 16.7 & 13.9 & 0.0 & 25.0 & 3 & 0.0 & 0.2 & 0.0 & 1.0 & 12 \\
\hline C1145 & 18.6 & 19.3 & 0.0 & 42.1 & 6 & 0.0 & 0.2 & 0.0 & 2.0 & 123 \\
\hline Wildtypes & 60.4 & 57.6 & 0.0 & 100.0 & 34 & 1.0 & 0.9 & 0.0 & 5.0 & 513 \\
\hline Azer16-50793 & 46.0 & 51.6 & 11.5 & 100.0 & 6 & 0.0 & 0.6 & 0.0 & 3.0 & 99 \\
\hline Azer16-50818 & 50.0 & 46.0 & 21.4 & 66.7 & 3 & 0.0 & 0.9 & 0.0 & 3.0 & 40 \\
\hline W6 47289 & 50.0 & 55.4 & 35.3 & 81.0 & 3 & 1.0 & 1.0 & 0.0 & 4.0 & 48 \\
\hline Azer-50824 & 54.6 & 58.3 & 46.7 & 73.7 & 3 & 1.0 & 0.9 & 0.0 & 3.0 & 45 \\
\hline Azer-50809 & 60.0 & 56.7 & 50.0 & 60.0 & 3 & 1.0 & 1.2 & 0.0 & 5.0 & 26 \\
\hline Azer-50803 & 64.7 & 60.0 & 40.0 & 70.6 & 4 & 1.0 & 0.7 & 0.0 & 3.0 & 74 \\
\hline Azer-50833 & 66.7 & 63.9 & 50.0 & 75.0 & 3 & 1.0 & 1.1 & 0.0 & 4.0 & 61 \\
\hline Azer-50865 & 75.0 & 50.9 & 0.0 & 77.8 & 3 & 1.0 & 1.4 & 0.0 & 4.0 & 18 \\
\hline Azer-50805 & 75.0 & 64.0 & 40.0 & 76.9 & 3 & 1.0 & 0.9 & 0.0 & 2.0 & 37 \\
\hline W6 40649 & 85.7 & 74.9 & 53.3 & 85.7 & 3 & 1.0 & 1.3 & 0.0 & 4.0 & 65 \\
\hline \multicolumn{11}{|l|}{ Susceptible control } \\
\hline Chosen & 74.0 & 69.6 & 33.3 & 100.0 & 6 & 2.0 & 1.5 & 0.0 & 5.0 & 76 \\
\hline
\end{tabular}

Table 9. ANOVA of the foliar disease incidence (FDI) and severity (FDS) in a randomized complete block design in Field 10 and Field 11 Expts. conducted in fields in Wellton and Yuma, Arizona, infested with Fusarium oxysporum f. sp. lactucae race 1.

\begin{tabular}{|c|c|c|c|c|c|c|c|c|c|c|c|c|c|c|c|c|}
\hline \multirow[b]{2}{*}{ Effect } & \multicolumn{8}{|c|}{ Field 11} & \multicolumn{8}{|c|}{ Field 12} \\
\hline & $\begin{array}{l}\text { Num } \\
\text { DF }\end{array}$ & $\begin{array}{l}\text { Den } \\
\text { DF }\end{array}$ & Value & $\operatorname{Pr}>F$ & $\begin{array}{c}\text { Num } \\
\text { DF }\end{array}$ & $\begin{array}{l}\text { Den } \\
\text { DF }\end{array}$ & Value & $\operatorname{Pr}>F$ & $\begin{array}{c}\text { Num } \\
\text { DF }\end{array}$ & $\begin{array}{l}\text { Den } \\
\text { DF }\end{array}$ & Value & $\operatorname{Pr}>F$ & $\begin{array}{c}\text { Num } \\
\text { DF }\end{array}$ & $\begin{array}{l}\text { Den } \\
\text { DF }\end{array}$ & Value & $\operatorname{Pr}>F$ \\
\hline Replicate & 3 & 54 & 401.32 & $<0.0001$ & 2.99 & 607 & 46.12 & $<0.0001$ & 2.25 & 4.6 & 19.86 & 0.0051 & 2.82 & 981 & 13.5 & $<0.0001$ \\
\hline Accession & 5.87 & 8.7 & 2.95 & 0.0075 & 10.5 & 372 & 28.46 & $<0.0001$ & 8.76 & 10.2 & 2.41 & 0.0107 & 2.94 & 12.6 & 6.75 & 0.0060 \\
\hline
\end{tabular}




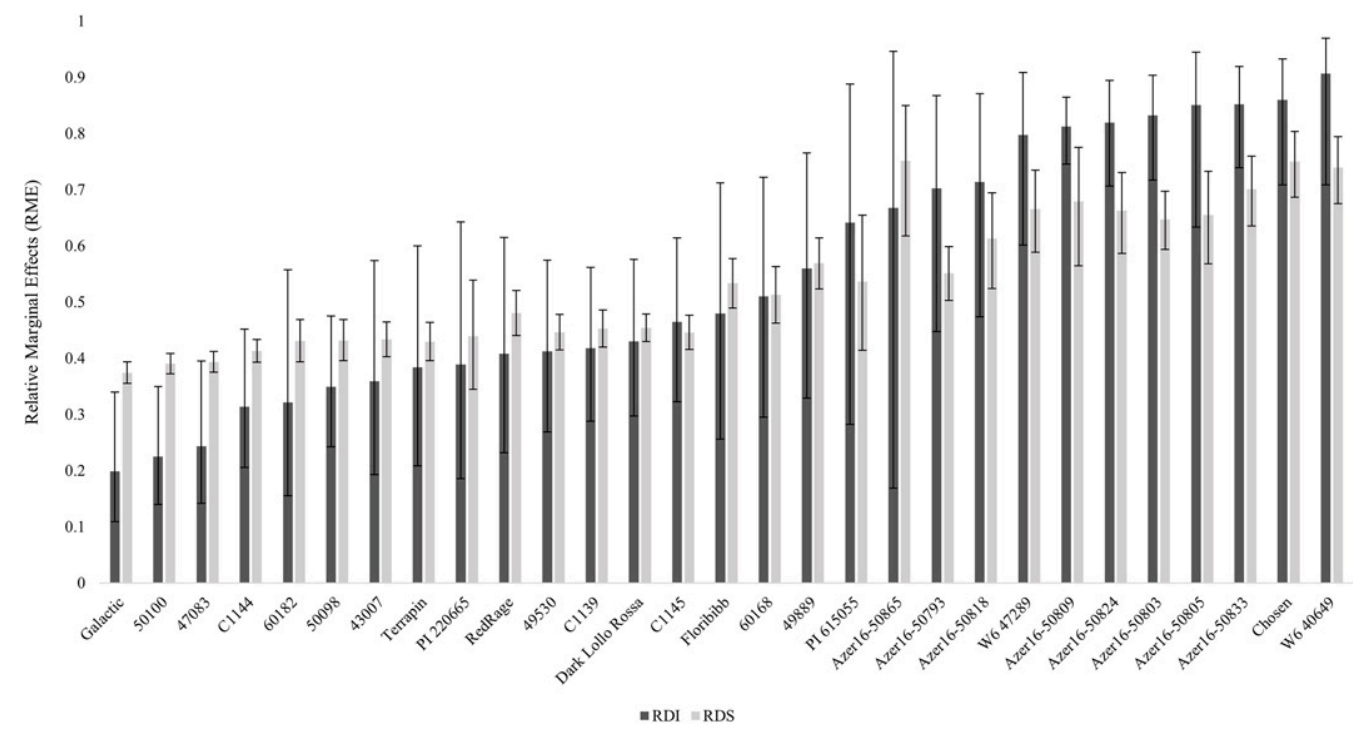

Fig. 2. Relative marginal effects (RME) for the root discoloration incidence (RDI) and severity (RDS) of accessions in Expt. Fields 9.1 and 9.2 tested in a field near Belle Glade, FL, naturally infested with $\mathrm{Fol}$ race 1. Error bars represent confidence intervals at 95\%.
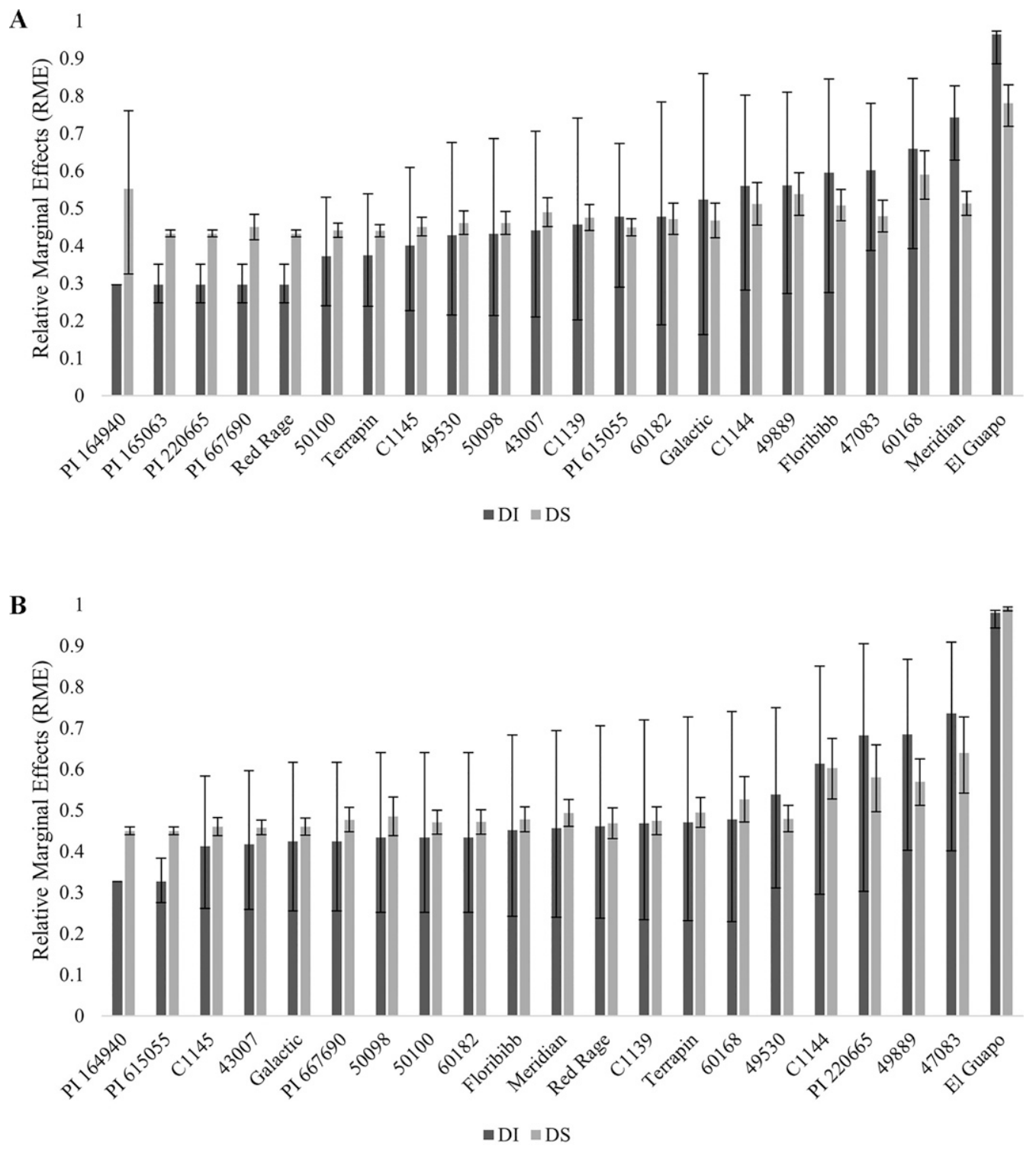

Fig. 3. Relative marginal effects (RME) for the foliar disease incidence (FDI) and severity (FDS) of accessions tested in a field naturally infested with Fol race 1 near Wellton (A) and Yuma (B). Error bars represent confidence intervals at 95\%. 
Table 10. Foliar disease incidence (FDI) and disease severity (FDS ${ }^{\mathrm{z}}$ dispersion measurements of 18 Lactuca accessions tested in a field naturally infested with $\mathrm{Fol}$ race 1 near Wellton, AZ (Field 11).

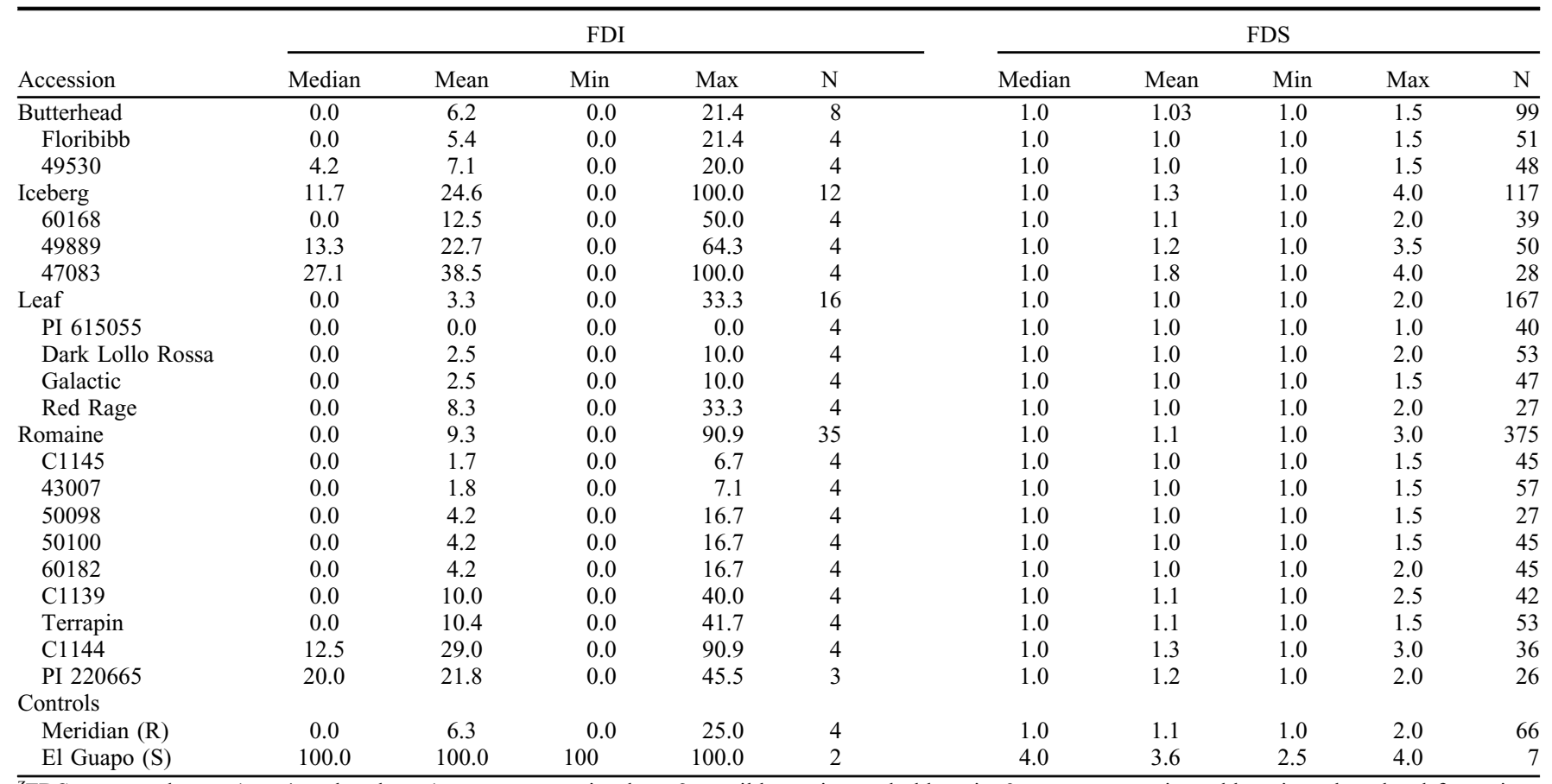

${ }^{\mathrm{z}}$ FDS was rated on a 1 to 4 scale where 1 = asymptomatic plant, $2=$ mild stunting and chlorosis, $3=$ severe stunting, chlorosis and no head formations and $4=$ a dead plant (Slinski et al., 2021).

UF/IFAS romaine breeding lines 43007, 50100, 60182, and C1144; iceberg breeding line 47083; and leaf cultivars Dark Lollo Rossa and Galactic. UF/IFAS cultivars that have demonstrated low foliar symptoms, but more substantial taproot colonization, included the romaine type Terrapin, the bibb Floribibb, and the iceberg Floricrisp 1265. The same resistance profile has been demonstrated by UF/IFAS breeding lines 49530 and C1145, as well as PI 615055. Leaf and romaine genotypes demonstrated lowest foliar and taproot symptoms overall. Butterhead and iceberg genotypes had higher, but similar, taproot symptoms; however, the butterhead genotypes displayed lower foliar symptoms in Arizona. Consistent resistance to root symptoms of $\mathrm{Fol}$ race 1 was not identified among the wildtype Lactuca tested in this study. Finally, the $\mathrm{F}_{2}$ segregation analysis conducted in this research suggests that using 'Dark Lollo Rossa' and 60182 as Fol race 1 resistance donors in breeding programs could provide complementary resistance alleles. Further genetic studies are necessary to understand

Table 11. Foliar disease incidence (FDI) and disease severity (FDS ${ }^{\mathrm{z}}$ dispersion measurements of 17 Lactuca accessions tested in a field infested with Fol race 1 near Yuma, AZ (Field 12).

\begin{tabular}{|c|c|c|c|c|c|c|c|c|c|c|}
\hline Accession & \multicolumn{5}{|c|}{ FDI } & \multicolumn{5}{|c|}{ FDS } \\
\hline Butterhead & 0.0 & 11.4 & 0.0 & 37.5 & 8 & 1.0 & 1.1 & 1.0 & 2.5 & 115 \\
\hline 49530 & 0.0 & 6.3 & 0.0 & 25.0 & 4 & 1.0 & 1.1 & 1.0 & 2.5 & 51 \\
\hline Iceberg & 10.6 & 14.5 & 0.0 & 63.6 & 12 & 1.0 & 1.3 & 1.0 & 4.0 & 139 \\
\hline 49889 & 5.6 & 18.7 & 0.0 & 63.6 & 4 & 1.0 & 1.3 & 1.0 & 3.0 & 48 \\
\hline 47083 & 8.9 & 9.4 & 0.0 & 20.0 & 4 & 1.0 & 1.1 & 1.0 & 4.0 & 42 \\
\hline Dark Lollo Rossa & 0.0 & 0.0 & 0.0 & 0.0 & 2 & 1.0 & 1.0 & 1.0 & 2.0 & 28 \\
\hline Red Rage & 0.0 & 0.0 & 0.0 & 0.0 & 4 & 1.0 & 1.0 & 1.0 & 1.0 & 50 \\
\hline PI 615055 & 3.9 & 3.9 & 0.0 & 7.7 & 4 & 1.0 & 1.0 & 1.0 & 2.0 & 56 \\
\hline Galactic & 7.7 & 7.7 & 0.0 & 15.4 & 2 & 1.0 & 1.1 & 1.0 & 2.0 & 28 \\
\hline Romaine & 0.0 & 6.5 & 0.0 & 41.7 & 31 & 1.0 & 1.1 & 1.0 & 4.0 & 418 \\
\hline 50100 & 0.0 & 1.4 & 0.0 & 5.6 & 4 & 1.0 & 1.0 & 1.0 & 3.0 & 61 \\
\hline Terrapin & 0.0 & 1.5 & 0.0 & 5.9 & 4 & 1.0 & 1.0 & 1.0 & 1.5 & 59 \\
\hline C1144 & 7.7 & 12.2 & 0.0 & 33.3 & 4 & 1.0 & 1.2 & 1.0 & 4.0 & 39 \\
\hline \multicolumn{11}{|l|}{ Controls } \\
\hline Meridian (R) & 17.4 & 16.0 & 7.4 & 21.9 & 4 & 1.0 & 1.2 & 1.0 & 3.5 & 111 \\
\hline El Guapo (S) & 69.2 & 64.3 & 36.4 & 82.4 & 4 & 2.0 & 2.1 & 1.0 & 4.0 & 65 \\
\hline
\end{tabular}

${ }^{\mathrm{z}}$ FDS was rated on a 1 to 4 scale where 1 = asymptomatic plant, $2=$ mild stunting and chlorosis, $3=$ severe stunting, chlorosis and no head formations and $4=$ a dead plant (Slinski et al., 2021). 
Table 12. Root discoloration severity (RDS) of two $\mathrm{F}_{2}$ populations from crosses 'Dark Lollo Rossa $\times$ PI 358001-1' and '60182 × PI 358001-1' inoculated

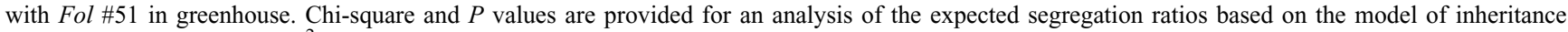
for a single resistant locus $\left(\chi_{\mathrm{df}}^{2}=1, \alpha=0.05=3.841\right)$.

\begin{tabular}{|c|c|c|c|c|c|c|c|c|c|c|c|c|c|c|}
\hline \multirow[b]{2}{*}{ Entry } & \multicolumn{6}{|c|}{ RDS } & \multirow[b]{2}{*}{$\mathrm{N}$} & \multirow[b]{2}{*}{ Obs. R:S } & \multicolumn{3}{|c|}{ Single recessive } & \multicolumn{3}{|c|}{ Single dominant } \\
\hline & 0 & 1 & 2 & 3 & 4 & 5 & & & Exp. R:S & $x^{2}$ & $P$ & Exp. R:S & $x^{2}$ & $P$ \\
\hline$\overline{\text { Dark Lollo Rossa (R) }}$ & 18 & 2 & 2 & 0 & 0 & 0 & 22 & $18: 4$ & & & & & & \\
\hline PI 358001-1 (S) & 3 & 6 & 8 & 3 & 1 & 0 & 21 & $3: 18$ & & & & & & \\
\hline $60182(\mathrm{PR})$ & 15 & 4 & 4 & 0 & 0 & 0 & 23 & $15: 8$ & & & & & & \\
\hline PI 358001-1 (S) & 4 & 3 & 6 & 3 & 4 & 0 & 24 & $4: 20$ & & & & & & \\
\hline $\mathrm{F}_{2} 60182 \times$ PI $358001-1$ & 61 & 27 & 126 & 48 & 13 & 21 & 296 & $61: 235$ & $74: 222$ & 3.04 & 0.0812 & & & \\
\hline
\end{tabular}

the number of loci controlling resistance in these accessions and whether these alleles will confer greater inhibition of taproot colonization or increased durability in $\mathrm{Fol}$ infested fields over time.

\section{Literature Cited}

Amaradasa, B.S., K. Beckham, N. Dufault, T. Sanchez, T.S. Ertek, F. Iriarte, M. Paret, and P. Ji. 2018. First report of Fusarium oxysporum f. sp. niveum race 3 causing wilt of watermelon in Florida, USA. Plant Dis. 102(5):1029, https://doi.org/10.1094/ PDIS-10-17-1649-PDN.

Aruga, D., N. Tsuchiya, H. Matsumura, E. Matsumoto, and N. Hayashida. 2012. Analysis of RAPD and AFLP markers linked to resistance to Fusarium oxysporum f. sp. lactucae race 2 in lettuce (Lactuca sativa L.). Euphytica 187(1):1-9, https://doi.org/10.1007/s10681-0120665-5.

Beharav, A. 2021. Lactuca georgica, a new wild source of resistance to downy mildew: Comparative study to other wild lettuce relatives. Eur. J. Plant Pathol. 160:127-136, https://doi. org/10.1007/s10658-021-02228-5.

Cabral, C.S., M.E.N. Fonseca, V.R. Oliveira, L.S. Boiteux, and A. Reis. 2019. A single dominant gene/locus model for control of Fusarium oxysporum f. $\mathrm{sp}$. lactucae race 1 resistance in lettuce (Lactuca sativa). Euphytica 215:114, https://doi.org/10.1007/s10681-019-2441-2.

Claerbout, J., S. Venneman, I. Vandevelde, A. Decombel, P. Bleyaert, A. Volckaert, J. Neukermans, and M. Höfte. 2018. First report of Fusarium oxysporum f. sp. lactucae race 4 on lettuce in Belgium. Plant Dis. 102(5):1037, https://doi.org/10.1094/pdis-1017-1627-pdn.

Datnoff, L., L. Liang, and R. Wick. 1997. Recent outbreak of Fusarium wilt of basil in Florida. Plant Dis. 81(10):1214, https://doi.org/10.1094/ PDIS.1997.81.10.1214C.

Desaeger, J., D.W. Dickson, and S.J. Locascio. 2017. Methyl bromide alternatives for control of rootknot nematode (Meloidogyne spp.) in tomato production in Florida. J. Nematol. 49(2):140-149, https://doi.org/10.21307/jofnem-2017-058.

Elliott, M.L. 2015. First report of Fusarium wilt caused by Fusarium oxysporum f. sp. canariensis on Phoenix reclinata in Florida. Plant Dis. 99(6):887, https:// doi.org/10.1094/PDIS-09-14-0897-PDN.

El-Sayed, S.F., N.E.-H.A. Reyad, A. Abdel-Wahab, and A.M. Hanafy. 2018. Occurrence of lettuce Fusarium wilt caused by Fusarium oxysporum f. sp. lactucae in Egypt and its management by using solarization, metam sodium and certain of bioproducts. Bioscience Research 15(2): 602-609.
Fang, X., M.P. You, and M.J. Barbetti. 2012. Reduced severity and impact of Fusarium wilt on strawberry by manipulation of soil $\mathrm{pH}$, soil organic amendments and crop rotation. Eur. J. Plant Pathol. 134:619-629, https://doi.org/ 10.1007/s10658-012-0042-1.

Garibaldi, A., G. Gilardi, and M.L. Gullino. 2002. First report of Fusarium oxysporum on lettuce in Europe. Plant Dis. 86(9): 1052, https://doi.org/10.1094/PDIS.2002. 86.9.1052B.

Garibaldi, A., G. Gilardi, and M.L. Gullino. 2004. Seed transmission of Fusarium oxysporum $\mathrm{f}$. sp. lactucae. Phytoparasitica 32(1):61-65, https://doi. org/10.1007/BF02980861.

Giesbers, A.K.J., E. den Boer, D.N.J. Braspenning, T.P.H. Bouten, J.W. Specken, M.P.W. van Kaauwen, R.G.F. Visser, R.E. Niks, and M.J.W. Jeuken. 2018. Bidirectional backcrosses between wild and cultivated lettuce identify loci involved in nonhost resistance to downy mildew. Theor. Appl. Genet. 131:1761-1776, https://doi.org/10.1007/s00122-018-3112-8.

Gilardi, G., S. Franco Ortega, P.C.J. van Rijswick, G. Ortu, M.L. Gullino, and A. Garibaldi. 2017a. A new race of Fusarium oxysporum f. sp. lactucae of lettuce. Plant Pathol. 66(4):677-688, https:// doi.org/10.1111/ppa.12616.

Gilardi, G., A. Garibaldi, S. Matic, M.T. Senatore, S. Pipponzi, A. Prodi, and M.L. Gullino. 2019. First report of Fusarium oxysporum f. sp. lactucae race 4 on lettuce in Italy. Plant Dis. 103(10):2680, https://doi.org/10.1094/PDIS-0519-0902-PDN.

Gilardi, G., C. Pons, B. Gard, S. Franco-Ortega, and M. Gullino. 2017b. Presence of Fusarium wilt, incited by Fusarium oxysporum f. sp. lactucae, on lettuce in France. Plant Dis. 101:1053, https://doi.org/10.1094/PDIS-12-16-1815-PDN.

Gordon, T.R. 2017. Fusarium oxysporum and the Fusarium wilt syndrome. Annu. Rev. Phytopathol. 55:23-39, https://doi.org/10.1146/annurevphyto-080615-095919.

Gordon, T.R. and S.T. Koike. 2015. Management of Fusarium wilt of lettuce. Crop Prot. 73:45-49, https://doi.org/10.1016/j.cropro.2015.01.011.

Gordon, T.R., M. Stueven, A.M. Pastrana, P.M. Henry, C.M. Dennehy, S.C. Kirkpatrick, and O. Daugovish. 2019. The effect of $\mathrm{pH}$ on spore germination, growth, and infection of strawberry roots by Fusarium oxysporum $\mathrm{f}$. sp. fragariae, cause of Fusarium wilt of strawberry. Plant Dis. 103:697-704, https:// doi.org/10.1094/PDIS-08-18-1296-RE.

Guerrero, M.M., M.C. Martínez, M. León, J. Armengol, and A. Monserrat. 2020. First report of Fusarium wilt of lettuce caused by Fusarium oxysporum f. sp. lactucae race 1 in Spain. Plant Dis. 104:1858, https://doi.org/ 10.1094/PDIS-10-19-2143-PDN.
Hubbard, J. and J. Gerik. 1993. A new wilt disease of lettuce incited by Fusarium oxysporum f. sp. lactucum forma specialis nov. Plant Dis. 77(7):750-754.

Komada, H. 1975. Development of a selective medium for quantitative isolation of Fusarium oxysporum from natural soil. Rev. Plant Protection Res. 8:114-124.

Lebeda, A., E. Křístková, M. Kitner, B. Mieslerová, M. Jemelková, and D.A.C. Pink. 2014. Wild Lactuca species, their genetic diversity, resistance to diseases and pests, and exploitation in lettuce breeding. Eur. J. Plant Pathol. 138:597-640, https://doi.org/10.1007/s10658-013-0254-z.

Maisonneuve, B., M. Pitrat, P. Gognalons, and B. Moury. 2018. Growth stage-dependent resistance to the potyviruses lettuce Italian necrotic virus and Lettuce mosaic virus displayed by Lactuca sativa introgression lines carrying the Mo3 locus from $L$. virosa. Plant Pathol. 67(9):2013-2018, https://doi.org/10.1111/ppa.12909.

Malbrán, I., C.A. Mourelos, M.S. Mitidieri, B.L. Ronco, and G.A. Lori. 2014. Fusarium wilt of lettuce caused by Fusarium oxysporum f. sp. lactucae in Argentina. Plant Dis. 98(9): 1281, https://doi.org/10.1094/PDIS-0414-0372-PDN.

Matheron, M.E. and S.T. Koike. 2003. First report of Fusarium wilt of lettuce caused by Fusarium oxysporum f. sp. lactucae in Arizona. Plant Dis. 87(10):1265, https://doi.org/ 10.1094/PDIS.2003.87.10.1265C.

Matheron, M.E. and M. Porchas. 2010. Evaluation of soil solarization and flooding as management tools for Fusarium wilt of lettuce. Plant Dis. 94(11):1323-1328, https://doi.org/10.1094/ PDIS-04-10-0296.

Matheron, M.E., J.D. McCreight, and B.R. Tickes. 2005. Effect of planting date, cultivar, and stage of plant development on incidence of Fusarium wilt of lettuce in desert production fields. Plant Dis. 89(6):565-570, https://doi.org/10.1094/PD-89-0565.

Matuo, T. and S. Motohashi. 1967. On Fusarium oxysporum f. sp. lactucae n.f. causing root rot of lettuce. Trans. Mycol. Soc. Japan 8:13-15.

McCreight, J.D., M.E. Matheron, B.R. Tickes, and B. Platts. 2005. Fusarium wilt race 1 on lettuce. HortScience 40(3):529-531, https://doi.org/ 10.21273/HORTSCI.40.3.529.

Michelmore, R.W., M.J. Truco, and O.E. Ochoa. 2017. Breeding crisphead and leafy lettuce. California Leafy Greens Research Program. 14 Mar. 2021. <https://calgreens.org/wp-content/uploads/ 2017/10/UCD-Lettuce-Breeding-Michelmore.pdf>.

Millani, M. 1999. Occurrence of Fusarium wilt of lettuce in Shahre-Ray, Varamin and Karaj areas. Iranian Journal of Plant Pathology 35:44 45.

Murray, J., R.N. Raid, C.F. Miller, and G. Sandoya-Miranda. 2020. First report of Fusarium oxysporum f. sp. lactucae causing vascular wilt of lettuce in Florida. Plant Dis. 104(11):3069, https://doi.org/10.1094/PDIS-12-19-2625-PDN. 
Owen, J.H. 1955. Fusarium wilt of cucumber. Phytopathology 45(8):435-439.

Pasquali, M., F. Dematheis, M.L. Gullino, and A. Garibaldi. 2007. Identification of race 1 of Fusarium oxysporum f. sp. lactucae on lettuce by inter-retrotransposon sequence-characterized amplified region technique. Phytopathology 97(8):987-996, https://doi.org/10.1094/ PHYTO-97-8-0987.

Pelgrom, A.J.E., J. Eikelhof, J. Elberse, C.N. Meisrimler, R. Raedts, J. Klein, and G. Van den Ackerveken. 2019. Recognition of lettuce downy mildew effector BLR38 in Lactuca serriola LS102 requires two unlinked loci. Mol. Plant Pathol. 20(2):240-253, https://doi.org/ 10.1111/mpp.12751.

Ploetz, R.C. and J.L. Haynes. 2000. First report of race 3 of Fusarium oxysporum f. sp. lycopersici in Southeastern Florida. Plant Dis. 84(2):199, https://doi.org/10.1094/PDIS.2000.84.2.199B.

Ploetz, R.C., A.J. Palmateer, D.M. Geiser, and J.H. Juba. 2007. First report of Fusarium wilt caused by Fusarium oxysporum on roselle in the United States. Plant Dis. 91(5):639, https:// doi.org/10.1094/PDIS-91-5-0639A.

Ploetz, R.C., J.L. Haynes, and A. Vázquez. 1999. Responses of new banana accessions in South Florida to Panama disease. Crop Prot. 18(7):445-449, https://doi.org/10.1016/ S0261-2194(99)00043-5.

Ryder, E.J. 1970. Inheritance of resistance to common lettuce mosaic. J. Amer. Soc. Hort. Sci. 95:378-379.

Ryder, E. 1999. Lettuce, Endive and Chicory. CABI Publishing, New York, NY.

Sandoya, G.V., M.J. Truco, L.D. Bertier, K.V. Subbarao, I. Simko, R.J. Hayes, and R.
Michelmore. 2021. Genetics of partial resistance against Verticillium dahliae race 2 in wild and cultivated lettuce. Phytopathology PHYTO-09, https://doi.org/10.1094/PHYTO09-20-0396-R.

Scott, J.C., T. Gordon, S.C. Kirkpatrick, S.T. Koike, M.E. Matheron, O.E. Ochoa, M.J. Truco, and R.W. Michelmore. 2012. Crop rotation and genetic resistance reduce risk of damage from Fusarium wilt in lettuce. Calif. Agr. 66(1):20-24, https://doi.org/10.3733/ca. v066n01p20.

Scott, J.C., T.R. Gordon, D.V. Shaw, and S.T. Koike. 2010a. Effect of temperature on severity of Fusarium wilt of lettuce caused by Fusarium oxysporum f. sp. lactucae. Plant Dis. 94(1):13-17, https://doi.org/10.1094/PDIS-94-1-0013.

Scott, J.C., S.C. Kirkpatrick, and T.R. Gordon. 2010b. Variation in susceptibility of lettuce cultivars to Fusarium wilt caused by Fusarium oxysporum f. sp. lactucae. Plant Pathol. 59(1):139-146, https:// doi.org/10.1111/j.1365-3059.2009.02179.x.

Scott, J.C., D.N. McRoberts, and T.R. Gordon. 2014. Colonization of lettuce cultivars and rotation crops by Fusarium oxysporum f. sp. lactucae, the cause of Fusarium wilt of lettuce. Plant Pathol. 63(3):548-553, https://doi.org/ 10.1111/ppa.12135.

Seki, K., K. Komatsu, M. Hiraga, K. Tanaka, Y. Uno, and H. Matsumura. 2020. Identification of two QTLs for resistance to Fusarium wilt race 1 in lettuce (Lactuca sativa L.). Euphytica 216:174, https://doi.org/10.1007/ s10681-020-02713-8.

Seki, K., K. Komatsu, M. Hiraga, K. Tanaka, Y. Uno, and H. Matsumura. 2021. Development of PCR-based marker for resistance to Fusarium wilt race 2 in lettuce
(Lactuca sativa L.). Euphytica 217(6):1-11, https://doi. org/10.1007/s10681-021-02857-1.

Sequiera, L. 1978. Two root rot resistant varieties of head lettuce. Ohio Agricultural Experimental Research Station Bulletin 359:197-214.

Shah, D.A. and L.V. Madden. 2004. Nonparametric analysis of ordinal data in designed factorial experiments. Phytopathology 94(1):33-43, https://doi.org/10.1094/PHYTO.2004.94.1.33.

Slinski, S.L., M.A. Pochas, H.V. Zima, and J.C. Correll. 2021. Evaluation of iceberg lettuce cultivars for resistance to Fusarium wilt, 2020. Plant Dis. Manag. Rep. V15: https://doi.org/ 10.1094/PDMR13.

Taylor, A., A. Jackson, and J. Clarkson. 2019. First report of Fusarium oxysporum f. sp. lactucae Race 4 causing lettuce wilt in England and Ireland. Plant Dis. 103(5): 1033, https://doi.org/10.1094/PDIS-10-181858-PDN.

Tsuchiya, N., M. Fujinaga, H. Ogiso, T. Usui, and M. Tsukada. 2004. Resistance tests and genetic resources for breeding Fusarium root rot resistant lettuce. J. Jpn. Soc. Hort. Sci. 73(2):105-113, https://doi.org/10.2503/jjshs. 73.105 .

University of Arizona. 2021. AZMET: The Arizona Meteorological Network. 8 Sept. 2021. $<$ https://cals.arizona.edu/azmet/index.html $>$.

University of Florida. 2021. FAWN: Florida Automated Weather Network. 8 Sept. 2021. $<$ https://fawn.ifas.ufl.edu/data/ $>$.

Ventura, J.A. and H. Costa. 2008. Fusarium wilt caused by Fusarium oxysporum on lettuce in Espirito Santo, Brazil. Plant Dis. 92(6):976. https://doi.org/10.1094/PDIS92-6-0976C. 